\title{
MANCHESTER
}

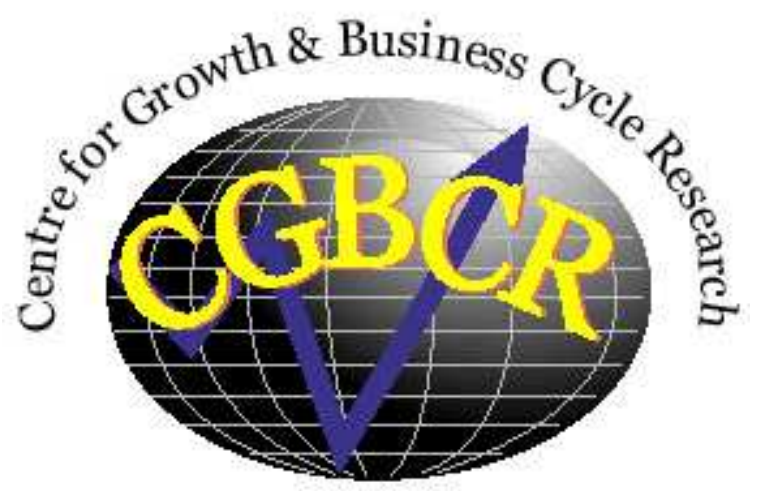

Discussion Paper Series

\section{Humanitarian Aid, Fertility, and Economic Growth}

By

\section{Kyriakos C. Neanidis}

Centre for Growth and Business Cycle Research, Economic Studies, University of Manchester, Manchester, M13 9PL, UK

May 2010

Number 139

Download paper from:

http://www.socialsciences.manchester.ac.uk/cgbcr/discussionpape rs/index.html 


\title{
Humanitarian Aid, Fertility, and Economic Growth
}

\author{
Kyriakos C. Neanidis \\ Economics, University of Manchester, United Kingdom \\ and Centre for Growth and Business Cycle Research
}

First complete draft: April 27, 2009

This version: January 4, 2009

\begin{abstract}
This paper examines the effect of humanitarian aid on the rates of fertility and economic growth in recipient countries. We develop a two-period overlapping generations model where reproductive agents face a non-zero probability of death in childhood. As adults, agents allocate their time to work, leisure, and child rearing activities of surviving children. Health status in adulthood exhibits "state dependence" as it depends on health in childhood. Humanitarian aid influences the probability of survival to adulthood, health in childhood, and the time adults allocate to child rearing, giving rise to an ambiguous effect on both the rates of fertility and growth. An empirical examination for the period 1973-2007 suggests that humanitarian aid has on average a zero effect on both the fertility rate and the rate of per capita output growth. The findings are robust to a wide number of sensitivity considerations.
\end{abstract}

Keywords: Aid; Fertility; Health; Growth

JEL Classification Numbers: C23; F35; F43; I12;O41 


\section{Introduction}

Recent years have witnessed a substantial increase in the number of studies exploring the relationship between foreign aid and economic growth. These studies, in their majority, assume that the way in which aid manifests and impacts on the economy is through the accumulation of physical or human capital (or a combination of the two). From these, the studies that highlight the human capital creation channel largely neglect the potential link between aid and demographic transitions in recipient nations. In light of the importance of a demographic transition for a transition in growth regimes within the unified growth theory, however, the likely effect of aid on fertility requires to be investigated. To this extent, this paper develops a theoretical framework complemented with an empirical analysis that jointly examines the impact of humanitarian aid on the levels of fertility and economic growth, thus offering a connection between aid and growth that relates to demographic considerations.

The aid-growth literature can be largely divided into two strands, the unconditional and the conditional. ${ }^{1}$ The first, advocates that aggregate aid has on average a positive growth effect either with or without diminishing returns (Hansen and Tarp (2001), Daalgard et al. (2004), and Economides et al. (2008)), while the second supports that aggregate aid impacts upon growth - either positively or negatively - only when particular conditions are in place. These conditions have been originally thought to reflect a good macroeconomic policy environment as captured by the recipient country's monetary, fiscal, and trade policies (Burnside and Dollar (2000)). A number of subsequent studies, however, have shown this finding to be fragile (see, for instance, Easterly et al. (2004) and Roodman (2004)) and suggested alternative recipient country characteristics as being important for the success (or failure) of foreign aid. Of these, the most influential are the timing of distributing aid during a negative terms of trade shock (Collier and Dehn (2001)) and after an armed civil conflict (Collier and Hoeffler (2002)), the geographic/tropical location of the recipient nation (Daalgard et al. (2004)), and, more recently, the power of the recipient's economic elites (Angeles and Neanidis (2009)). In addition, some other studies have examined the growth effect of different categories of aid, as these are represented by the short-impact, long-impact, and humanitarian aid (Clemens et al. (2003)), geostrategic and non-geostrategic aid (Headey (2007)), tied and untied aid (Miquel-Florensa (2007)), and productive and pure aid (Chatterjee et al. (2003), Minoiu and Reddy (2009), and Neanidis and Varvarigos (2009)).

At the same time, development theorists view fertility considerations as an integral part of the transition process from a near-zero steady state growth regime to one with positive rates of growth. This mechanism dates back to Becker (1960) where fertility decisions are based on a quantity-quality tradeoff for children. This tradeoff arises because the utility of parents depends both on the number of children and on

\footnotetext{
${ }^{1}$ Clemens et al. (2004) offer an excellent review of the two groups, while Doucouliagos and Paldam (2008) offer a meta-analysis of the literature.
} 
their quality, as captured by their level of human capital. Given that human capital accumulation arises through investments in education, and that both child rearing activities and education are costly, a tradeoff emerges. In this context, the idea that changes in mortality largely determine fertility outcomes finds a natural framework to make educational investment more attractive, and, therefore, lead parents to choose child quality over child quantity. This, in turn, causes a simultaneous decline in fertility and an increase in human capital accumulation and growth, thus providing a link between transitions in demography and growth. Recent contributions along these lines include Galor and Weil (2000), Blackburn and Cipriani (2002), Kalemli-Ozcan (2003), Moav (2005), Cervellati and Sunde (2005), and Azarnert (2006). More recently, however, some studies have considered human capital accumulation not as a function of educational attainment but as a function of investments in health. In this way, life expectancy depends on health expenditures made from either the government (Chakraborty (2004)) or the individuals themselves (Bhattacharya and Qiao (2007)).

This paper jointly studies the impact of humanitarian aid on the rates of fertility and economic growth of recipient nations, and in this way offers a combination of the two abovementioned literatures. Our theoretical analysis builds upon the contribution of Agénor (2009) but is most closely related in nature to Azarnert (2008). Agénor (2009) develops a three-period OLG model, which although allows fertility choices to be endogenous as in the previous literature, it abstracts from human capital accumulation. In this case, the quantity-quality tradeoff of children that arises does not depend on the fertility and educational choices of parents but on the choice between fertility and the time parents allocate to child rearing activities. Thus, the endogeneity of life expectancy is directly related to health status, rather than human capital arising from educational choices. Given that the health status of children depends on parents child rearing time, the latter is indirectly productive since not only it improves childrens' health but also their health later in life. As a result, time allocated to child care is treated endogenously. In addition, the paper accounts for the fact that health outcomes in childhood may affect health outcomes in adulthood. It also assumes that it is "effective" labor that is used in production; and individuals can provide effective labor services only if they are healthy. In this way, by enhancing productivity, health status influences growth indirectly. Therefore, persistence in health gives rise to a sustainable equilibrium of on going growth.

Azarnert (2008), on the other hand, represents the first study to simultaneously tackle the influence of foreign aid on population growth and human capital accumulation. By distinguishing two types of aid, per adult and per child, he shows that both categories increase fertility by reducing the quantity cost of children. As an outcome, parents invest less in the education of their offsprings leading to a slowdown in human capital accumulation, which may even lock the recipient economy in a poverty trap. Azarnert (2008), therefore, draws a relatively gloom picture of the effects of humanitarian aid. At the same time, however, he neglects the potentially beneficial impact of this type of aid on the rate of survival from childhood to adulthood as documented by a number of studies (Huff and Jimenez (2003), De Waal etal. (2006), and Plumber 
and Neumayer (2009)). In addition, his analysis abstracts from the promoting effect of aid on children's health status through the greater intake of (nutritious) food and of vaccination campaigns (see, for instance, Kraak et al. (1999) and the Center for Global Development Brief (2007)). Accounting for these considerations in our model allows us to provide a more complex effect of humanitarian aid that gives rise to conflicting influences on both fertility and economic growth. Such an impact is also consistent with the empirical evidence provided in this paper. ${ }^{2}$

In particular, our theoretical analysis is a simplified version of Agénor (2009) that also incorporates humanitarian aid. It is a two-period OLG model that accounts for the endogeneity of parent's time allocation to child rearing activities, and in this way allows them to internalize the impact of their decisions. ${ }^{3}$ As in Azarnert (2008), aid is allocated to every adult and child in the economy. Unlike him, however, only per adult aid comes in monetary form. Per child aid is in kind to reflect the flows of food, medication, and vaccinations offered by donors. It is this type of aid that raises the probability of a child's survival to the next period of life (adulthood), thereby reducing fertility, while at the same time contributes directly to children's health status. This in turn, has a positive effect on growth. Monetary per-adult aid, on the other hand, and consistent with Azarnert (2008), increases fertility by reducing the quantity cost of children, thereby shifting resources from quality of children to quantity. At the same time it reduces the child-rearing time of adults, which in turn lowers the health status of both children and adults, and subsequently the rate of economic growth. Therefore, the effect of humanitarian aid on both the rates of fertility and growth of per worker output in our model, and in contrast to Azarnert (2008), is found to be ambiguous.

Given the ambiguity of the theoretical analysis, we resort to an empirical evaluation of these effects. The empirical analysis considers 66 aid-recipient nations and undertakes static and dynamic panel data estimations over the period 1973-2007 (in four-year period averages). We estimate the effects of humanitarian aid, as this is proxied by the classification methodology of Clemens etal. (2004) and Neanidis and Varvarigos (2009), on both the fertility rate and rate of per capita output growth. The empirical methodology considers both reduced form estimations and joint estimations of the fertility and growth equations. Our results suggest that humanitarian aid has on average a zero impact on both the rate of fertility and the rate of output growth, implying that the two conflicting effects of humanitarian aid outlined by our theoretical illustration fully offset each other. An exception to this general finding, pointing to a positive fertility effect, is documented for the countries that have not yet experienced the demographic transition characterized by high fertility rates. These findings are robust to the inclusion of a wide number of sensitivity considerations including

\footnotetext{
${ }^{2}$ Azarnert (2008) also provides some preliminary empirical evidence, which however is not systematically conducted with regression techniques.

${ }^{3}$ This is quite important because the time allocated to child care is quite significant in developing countries - around one hour a day in most cases, but between one and two hours in countries like Bangladesh, Botswana, Kenya, and the Philippines (see Brown and Haddad (1995)) and up to three hours in a country like Nicaragua (see Ilahi (2000)).
} 
different estimation and instrumentation techniques, exclusion of outliers, alternative measures of aid, regression specifications, aid-interaction effects, and alternative period averaging.

The remainder of the paper is organized as follows. Section 2 presents the theoretical analysis, setting out and solving our model economy to establish the key implications. It also offers a robustness test to our main results by adding a third type of aid, monetary assistance for each child, as also done by Azarnert (2008). Section 3 contains the empirical analysis, describing our methodology and data, presenting our basic findings and reporting on the results of extensive robustness tests. Section 4 contains a few concluding remarks.

\section{Theory}

Consider a small OLG economy in which activity extends over an infinite discrete time period. In every period one homogeneous good is produced, which can be only consumed in that period, with labor as the single input. In each generation individuals live (at most) for two periods: childhood and adulthood. Each individual is endowed with one unit of time in childhood and two units in adulthood. Children depend on their parents for consumption and health care. Adults supply inelastically one unit of labor at a determined wage rate, which serves to finance consumption in adulthood and raise children. Adult agents also receive a permanent flow of monetary aid from external donors.

In adulthood, each individual becomes a parent and bears $n$ children. All children are born with the same innate abilities and the same initial health status. However, keeping children healthy involves a cost, both in terms of the parent's time and spending on marketed goods (food, medicines, etc.). Adults must decide on the allocation of their non-work unit of time between child rearing and leisure.

At the beginning of the first period of life there is a non-zero probability of dying, which is decreasing in the amount of in kind (food and medical) aid consumed. The health status of children and adults are taken to depend on different determinants, in line with the evidence of Cutler et al. (2006). For children, health status depends on the time parents allocate to rearing their offspring, on in kind aid, and on the parent's health. The latter effect is consistent with the evidence provided by Powdthavee and Vingoles (2008) for Britain, suggesting that parents' physical and mental health (beyond short-term stress and strain) affects their children's well-being. ${ }^{4}$ For adults, health status is taken to depend on health status in childhood indicating "state dependence" in health outcomes. This specification is consistent with the evidence of Case et al. (2005), according to which children who experience poor health have on average

\footnotetext{
${ }^{4}$ Alternatively, it could be assumed that cognitive and physical impairments of children may begin in utero, due to inadequate nutrition and poor health of the mother. The importance of the prenatal environment is supported by Bloom and Canning (2005) who estimate that 30 million infants are born each year in developing countries with impaired growth due to poor nutrition during fetal life.
} 
significantly poorer health as adults. Finally, all markets clear and there are no debts or bequests between generations.

\subsection{Population}

Let $N_{t}$ be the number of adults in period $t$. Given that at the beginning of their adult life in $t$, each individual bears $n_{t}$ children, the total number of children born at the beginning of that period is $n_{t} N_{t}{ }^{5}$ The probability of survival from childhood to adulthood (at the beginning of period $t$ ) is denoted by $p_{t} \in(0,1)$. For tractability, we do not account explicitly for the random nature of the number of surviving children; the number of surviving children is simply given by the expected number of survivors. To avoid convergence of population size toward zero, we assume that $p_{t} n_{t} \geq 1$. All these imply that the number of surviving children is $p_{t} n_{t} N_{t}$. Thus, total population at the beginning of period $t$ is $\left(1+p_{t} n_{t}\right) N_{t}$. Moreover, the number of adults alive in period $t$ is equal to the number of children born in the previous period, $N_{t-1} n_{t-1}$, who survived to period $t$, that is,

$$
N_{t}=p_{t-1} N_{t-1} n_{t-1} .
$$

Aggregate population at the beginning of period $t, L_{t}$, is thus

$$
L_{t}=\left(1+p_{t} n_{t}\right) p_{t-1} n_{t-1} N_{t-1}
$$

\section{$2.2 \quad$ Humanitarian Aid}

We assume that each period foreign donors with altruistic motives provide humanitarian aid to the economy in the form of pure transfers of real resources. ${ }^{6}$ These transfers come in two forms: monetary aid per adult individual, $A^{a}$, and in kind aid per child, $A^{f} .^{7}$ Monetary aid is measured in units of effective labor income, a necessary assumption to sustain an equilibrium of on-going growth. ${ }^{8}$ Therefore

$$
A^{a}=a \alpha_{t+1} w_{t+1}, \quad a \in(0,1),
$$

\footnotetext{
${ }^{5}$ For tractability, the number of children is assumed to be continuous. Integer restrictions are thus neglected.

${ }^{6}$ Humanitarian considerations do play a role for the allocation of aid by foreign donors as evident in Ball and Johnson (1996) and Svensson (2000). The determination of humanitarian aid by donors, exogenous to the recipient, is also consistent with the operation of aid provision within the OECD's Creditor Reporting System (CRS) and Donor Assistance Committee (DAC), which report commitments and distributions of aid of donors by purpose.

${ }^{7}$ In kind per child aid could also be monetized, as the majority of U.S. Title II PL 480 food aid is for Kenya and Uganda (Kraak et al. (1999)). As long as part of this assistance is used for the subsistence needs of children, even in the presence of aid fungibility, the implications of our model are not distorted. In a later section, following Azarnert (2008), we also examine the explicit addition of monetary per child aid, $A^{c}$.

${ }^{8}$ We could instead assume as in Chatterjee et al. (2003) that monetary aid is measured in units of domestic output, that is, tied to the scale of the economy. As it will become clear later on, however, in equilibrium it makes no difference which of the two assumptions is used.
} 
where $\alpha_{t+1}$ is individual labor productivity and $w_{t+1}$ the real wage rate. In kind aid, on the other hand, represents food and medical aid targeted to the most vulnerable of the population groups, children, given that a stated goal of food aid is 'to combat malnutrition, especially in children' (PL 480, as quoted in Ball and Johnson 1996, p. 517). Kraak et al. (1999) in a study of the role of food aid in countries with an AIDS epidemic have found that food aid directly benefits the poor through supplementary feeding programs while it improves the quality of diet of people living with HIV/AIDS. At the same time, it allows the availability and access of more nutritious food to children. ${ }^{9}$ In addition, a study by De Waal et al. (2006) examining the effects of the 2002-2003 drought in Ethiopia has unveiled that 'household receipt of food aid had a small but significantly positive association with child survival'. This outcome also finds support by Huff and Jimenez (2003) who state that 'emergency food aid has been shown to play a role in saving lives and limiting nutritional distress' and by Plumber and Neumayer (2009) who find international food aid to negatively affect famine mortality. At the same time, as reported in the Center for Global Development Brief (2007), medical aid in the form of vaccines and increased awareness has almost eliminated measles as a cause of childhood death in seven African countries in southern Africa, freed 18 million children from the risk of river blindness in 11 West African countries since 1974, and reduced infant deaths in Egypt due to diarhea by 82\% between 1982 and 1989.

The above clearly illustrate the role of in kind aid in increasing children's likelihood of survival, especially in regions where food is scarce and health conditions in a freefall. Thereby, and in line with the above evidence, we assume that the probability of survival from childhood to adulthood is enhanced by in kind aid, $p_{t}\left(A^{f}\right)$ with $p_{t}^{\prime}\left(A^{f}\right)>0 .{ }^{10}$

\subsection{Households}

As already noted, at the beginning of their adult life in $t+1$, each individual bears $n_{t+1}$ children. Raising a child involves two types of costs. First, parents spend $\varepsilon_{t+1} \in(0,1)$ units of time on each of them to take care of their health (breast feeding, taking children to medical facilities for vaccines, etc.). Each adult allocates $\varepsilon_{t+1} n_{t+1}$ units of time to that activity. Second, raising children involves costs in terms of marketed goods. These costs relate to feeding children, taking them to medical facilities, buying medicines, etc. Specifically, each individual spends a fraction $\theta \in(0,1)$ of his adult income on each child's health. Thus, although access to "out of home" health services per se is free, families face a cost in terms of foregone wage income and consumption.

\footnotetext{
${ }^{9}$ Such food is necessary, especially for children that suffer from HIV/AIDS as they need to take their antiretroviral medication on a full stomach.

${ }^{10}$ Alternatively, it could be assumed that the probability of survival exhibits threshold effects with regard to children health status. This would imply that as health status improves above a threshold, the probability of survival increases. Such a consideration, however, would unnecessarily complicate the analysis and lead to multiple equilibria, an issue beyond the main point of this paper. For a formal illustration see Agénor (2009).
} 
Let $y_{t+1}$ denote the individual's income in $t+1$; the total cost of raising $n_{t+1}$ children - should all of them survive - is thus given by the sum of the opportunity cost in terms of foregone wage earnings and the opportunity cost in terms of foregone consumption, that is, $\left(\varepsilon_{t+1}+\theta\right) n_{t+1} y_{t+1}$. Thus, as is standard in the literature (see, for instance, Barro and Becker (1989), Galor and Weil (2000), and Azarnert (2008)), the existence of these costs creates a trade-off between the quality and quantity of children. This cost, however, is not with respect to education but with respect to health.

Assuming that consumption of children in the first period of life is subsumed in their parents' consumption, lifetime utility at the beginning of period $t+1$ of a (surviving) agent born at $t$ is specified as

$$
\begin{gathered}
U_{t+1}=\ln c_{t+1}^{t}+\eta_{L} \ln \left(1-p_{t+1}\left(A^{f}\right) n_{t+1} \varepsilon_{t+1}\right) \\
+\eta_{N} \ln p_{t+1}\left(A^{f}\right) n_{t+1} h_{t+1}^{C},
\end{gathered}
$$

where $c_{t+j}^{i}$ denotes consumption of generation $i$ individuals at date $t+j$. The term $1-p_{t+1}\left(A^{f}\right) n_{t+1} \varepsilon_{t+1}$ measures leisure in adulthood, whereas coefficients $\eta_{L}$ and $\eta_{N}$ measure the individual's relative preference for leisure and surviving healthy children.

The term $p_{t+1}\left(A^{f}\right) n_{t+1} h_{t+1}^{C}$ is equal to actual family size $p_{t+1}\left(A^{f}\right) n_{t+1}$-which differs from fertility (the number of children per individual), $n_{t+1}$, because the child survival rate is less than unity - multiplied by the health status of a child, $h_{t}^{C}$. In the standard literature, parents derive utility from the "raw" production of offspring. Here, however, it is the expected number of healthy children that matters.

Suppose that child mortality occurs only at the beginning of the period, so parents incur no rearing costs for children who die before adulthood. ${ }^{11}$ Because there is no consumption in childhood, the period-specific budget constraint is

$$
c_{t+1}^{t}=\left[1-\theta p_{t+1}\left(A^{f}\right) n_{t+1}\right] \alpha_{t+1} w_{t+1}+A^{a} .
$$

Note that although $\theta$ itself is not a decision variable, it could be made a function of either (or both) in kind or monetary aid. Both types of aid receipts would normally lead parents to spend a smaller fraction of their labor income on children's rearing, so that $\theta=\theta\left(A^{f}, A^{a}\right)$, with $\theta_{A^{f}}^{\prime}<0$ and $\theta_{A^{a}}^{\prime}<0$. This would offer yet another channel through which humanitarian aid may affect fertility and growth. However, as it will be shown later, this consideration will not influence our findings. For simplicity, therefore, $\theta$ will be kept constant throughout.

\section{$2.4 \quad$ Firms}

We assume a simple technology where aggregate output is given by

$$
Y_{t}=B_{t} N_{t}
$$

\footnotetext{
${ }^{11}$ Alternatively, it could be assumed that rearing costs are incurred for all children, regardless of whether they survive or not. The assumption in the text is more natural, given that in many poor countries mortality in childhood tends to occur early in the life of children.
} 
where $B_{t}$ denotes average, economy-wide labor productivity (which is the same for all firms) and $N_{t}$ the number of adult workers employed. Thus, production exhibits constant returns to scale in effective labor $B_{t} N_{t}$, which in the steady state gives rise to endogenous growth.

\subsection{Health Status and Productivity}

In line with the evidence of Cutler et al. (2006), the health status of children and adults are not determined by the same factors. The health status of a child, $h_{t}^{C}$, depends on the income spent on goods for each child, in kind aid, the parent's health status, $h_{t}^{A}$, and the time allocated by their parent to rearing them:

$$
h_{t}^{C}=\theta\left(A^{f}\right)\left(h_{t}^{A}\right)\left(\varepsilon_{t}\right)^{\nu}
$$

where $\nu \in(0,1)$ is an efficiency parameter. First, a child's health status is linear in the share of resources spent by the parent, $\theta$, and in the amount of in kind aid consumed, $A^{f}$, because both help to improve his health and nutrition, thereby reducing their vulnerability to disease (see for instance Pelletier et al. (2003), Caulfield et al. (2004) and the references in section 2.2). Second, a child's health depends on the parent's health. This may be related to the impact of parents' mental distress and anxiety on children's life satisfaction (see Larson and Gillman (1999) and Downey et al. (1999)) and their physical ability to take care of their children (which may require walking long distances, on difficult terrain, to take them to medical facilities). It could also reflect Barker's (1998) "fetal origins hypothesis" which suggests that conditions in utero have long lasting effects on an individual's health. Almond (2006) finds that cohorts in utero during the influenza epidemic of 1918, which affected a third of women of child-bearing age, were more likely to be too disabled to work compared to cohorts immediately before or after the epidemic. The affected cohorts were also experiencing lower educational attainment and lower wages. ${ }^{12}$ Third, the health status of a child depends on the time allocated to him by his parent. ${ }^{13}$

The health status of adults depends (linearly) on their health status in childhood. This is in line with growing evidence suggesting that late life health is the outcome of a cumulative process of exposure to health risks in childhood, especially infectious diseases in the first years of life. By determining health outcomes later in life, health in childhood may therefore play a critical role in the determination of socioeconomic status in adulthood (Strauss and Thomas (1998)). Fogel (1994) has shown that better nutrition in childhood, in the first half of the twentieth century, affected the health and life-span during the adult years of life. Similarly, using data from the Panel Survey of Income Dynamics in the United States covering 30 years, Smith (2008) found that

\footnotetext{
${ }^{12}$ Note that the impact of the in utero linkage would be to include $h_{t-1}^{A}$ instead of $h_{t}^{A}$ in equation (7). If so, however, one would need to assume that adult health in $t+1$ generates direct utility.

${ }^{13}$ Health status at birth, which could be accounted for by adding a linear term $\bar{h}^{C}>0$ in $(7)$, is ignored for tractability.
} 
poor childhood health has a quantitatively large effect on individual earnings and labor supply, as well as family income and household wealth. ${ }^{14}$ Given this evidence, we specify:

$$
h_{t+1}^{A}=h_{t}^{C}
$$

Substituting (7) in (8) yields

$$
h_{t+1}^{A}=\theta\left(A^{f}\right)\left(h_{t}^{A}\right)\left(\varepsilon_{t}\right)^{\nu} .
$$

Thus, because a parent's health affects his children's health, or equivalently because adult well being depends on own health in childhood, there is serial dependence in $h_{t}^{A}$. In the spirit of Grossman's (1972) approach, health is therefore viewed as a durable stock - which can be increased here not only by spending more on goods but also by allocating more time to taking care of one's brood. ${ }^{15}$

As in Agénor (2009), adult productivity is taken to be linear in health status:

$$
\alpha_{t}=h_{t}^{A}
$$

\subsection{Long-Run Equilibrium}

In this simple model, the market-clearing condition for the goods market is

$$
Y_{t}=C_{t}=N_{t}\left[c_{t}^{t}+\theta p_{t}\left(A^{f}\right) n_{t} \alpha_{t} w_{t}\right]
$$

representing total consumption spending at $t$.

The following definition may therefore be proposed:

Definition 1. A competitive equilibrium for this economy is a sequence of prices $\left\{w_{t}\right\}_{t=0}^{\infty}$, allocations $\left\{c_{t+1}^{t}, \varepsilon_{t+1}\right\}_{t=0}^{\infty}$, and health status of children and adults $\left\{h_{t}^{C}, h_{t}^{A}\right\}_{t=0}^{\infty}$ such that individuals maximize utility, firms maximize profits, and markets clear.

In equilibrium, individual productivity must also be equal to the economy-wide average productivity, so that $\alpha_{t}=B_{t} \cdot{ }^{16}$ In addition, to keep things as simple as possible, we assume that children of all generations face an identical probability of survival to adulthood being constant at $p_{t}\left(A^{f}\right)=p_{t+1}\left(A^{f}\right)=p\left(A^{f}\right)$. With this assumption, the following definition characterizes the balanced growth path:

Definition 2. A balanced growth equilibrium is a competitive equilibrium in which $c_{t}^{t}, c_{t+1}^{t}, h_{t}^{C}, h_{t}^{A}$, and $Y_{t} / N_{t}$, all grow at the constant endogenous rate $1+\gamma$.

\footnotetext{
${ }^{14}$ Health in childhood may also affect health and income in adulthood through education. For a discussion, see Agénor (2009).

${ }^{15}$ See Becker (2007) for a recent overview of Grossman's approach and the subsequent literature. The analysis could be extended to account for the possibility that the stock of health depreciates with age.

${ }^{16}$ This in turn implies, that, given the firm's profit maximization condition $w_{t}=1$, in equilibrium it makes no difference whether monetary aid per adult is tied to total output per capita $\left(B_{t}\right)$ or effective labor income $\left(\alpha_{t}\right)$.
} 


\subsection{Fertility, Time Allocation, and Growth}

Each adult maximizes (4) subject to (3), (5), (7), and (8), with respect to $c_{t+1}^{t}, \varepsilon_{t+1}$, and $n_{t+1}$, taking $a$ and $p\left(A^{f}\right)$ as given, but also taking into account the impact of their decisions regarding $\varepsilon_{t+1}$ on the health status of their children and of their own.

The solution of the household problem is provided in Appendix A. It shows that in equilibrium, $n_{t+1}$ and $\varepsilon_{t+1}$ are both constant:

$$
\begin{gathered}
\tilde{n}=\frac{\eta_{N}(1-\nu)(1+a)}{\theta p\left(A^{f}\right)\left[1+\eta_{N}(1-\nu)\right]}>0, \\
\tilde{\varepsilon}=\Lambda \frac{\theta\left[1+\eta_{N}(1-\nu)\right]}{\eta_{N}(1-\nu)(1+a)}>0,
\end{gathered}
$$

where $\Lambda \equiv \eta_{N} \nu /\left(\eta_{L}+\eta_{N} \nu\right)>0 .{ }^{17}$ The following assumption must be imposed to ensure that $p\left(A^{f}\right) \tilde{n} \geq 1$, as noted earlier:

Assumption 1: $\theta \leq \eta_{N}(1-\nu)(1+a) /\left[1+\eta_{N}(1-\nu)\right]$.

Thus, the fraction of income spent on caring for each child cannot be too large. From the solutions (12) and (13), the following proposition can be established:

Proposition 1. An increase in humanitarian aid has an ambiguous effect on fertility rate and reduces the time parents allocate to surviving children. In particular, in kind aid reduces fertility and has no impact on parent's child rearing time, while monetary aid increases fertility and reduces parent's child rearing time.

In kind aid has a negative effect on fertility by increasing the probability of survival from childhood to adulthood. The fact that the fertility rate is inversely related to the survival probability is consistent with the result established by Agénor (2009), where an increase in the survival probability reduces the precautionary demand for children. This finding is also consistent with Kalemli-Ozcan (2003) in a stochastic setting that accounts explicitly for educational choices and ex ante uncertainty about the number of surviving children. ${ }^{18}$ Monetary per-adult aid, on the other hand, increases fertility by reducing the "quantity cost" of children, thereby shifting resources from quality of children to quantity of children. Therefore, and in line with Azarnert (2008), per adult aid increases the return on child quantity.

\footnotetext{
${ }^{17}$ It is easily shown that $p\left(A^{f}\right) \tilde{n} \tilde{\varepsilon}=\Lambda<1$, which implies that the time allocation is feasible and that leisure is positive in equilibrium.

${ }^{18}$ Note that, as in Agénor (2009), there exists a proportional relationship between children's survival probability and the number of births. Even though this result contrasts the empirical evidence, which supports a less-than-proportional relationship (as in fact our empirical analysis confirms below), there are ways to break the linearity in our model. One way, would be to assume that the children who die prematurely generate a cost for their parents. Another, is to assume either that the probability of survival exhibits threshold effects with respect to total parental spending on rearing each child (Azarnert (2006)), or with regard to children health status (see footnote 10). Although such considerations would improve the quantitative size of the effects, the qualitative implications of our model would not change. For this reason, we prefer the analytical tractability.
} 
The effect of humanitarian aid on parent's child rearing time, is captured only through the negative effect of per adult aid. This is consistent with the results of Azarnert (2008), although in his model aid does not reduce child rearing time but decreases the investment of parents to their children education, and the subsequent accumulation of human capital. The implication, however, is fundamentally the same. In kind aid is found not to have an effect on the time allocated to child rearing because, as in Agénor (2009), the increase in the survival probability is exactly offset by the reduction in the number of children. In addition, $\tilde{\varepsilon}$ does not depend on $p\left(A^{f}\right)$ because it is the actual number of children that matters for the allocation of time. This is a consequence of the log-linear utility function chosen here. As will be shown later, the inclusion of per child monetary aid will give rise to a relationship between survival probability and parent's child rearing time. ${ }^{19}$

We next derive the balanced growth rate of the economy in Appendix A. The balanced growth rate of output per worker is

$$
1+\gamma=\theta^{(1+\nu)}\left(A^{f}\right)\left\{\Lambda \frac{\left[1+\eta_{N}(1-\nu)\right]}{\eta_{N}(1-\nu)(1+a)}\right\}^{\nu} .
$$

Equation (A15) implies that the model has no transitional dynamics. Following a shock, the time adults allocate to child rearing must jump immediately to its new equilibrium value. It then follows from (14) that the economy is always on its balanced growth path. From (A13) it is also clear that the health status of both adults and children, $h_{t}^{A}$ and $h_{t}^{C}$, grow at the same constant rate.

Equation (14) can be used to examine the impact of humanitarian aid on long-run growth. In particular, the following result holds:

Proposition 2. An increase in humanitarian aid has an ambiguous effect on the growth rate of output per worker. In particular, in kind aid increases while monetary aid reduces the rate of per worker output growth.

The reason why an increase in humanitarian aid has an unclear effect on the growth rate has to do with the opposing effects of in kind and per adult aid. In kind aid has a positive impact on growth by directly enhancing the health status of surviving children and their productivity during adulthood. Aid per adult, on the other hand, reduces the child-rearing time adults allocate to their children, which lowers children health status. This, in turn, reduces health status in adulthood, and subsequently the rate of economic growth. The positive growth effect of in kind aid is in line with the evidence provided by Bezuneh et al. (2003) who find a sustained 1 percent increase in food aid to promote per capita income growth by about 2 US dollars in Tunisia. The effect of per adult aid, on the other hand, finds support in Azarnert (2008), which, as described before, reduces human capital accumulation and growth.

\footnotetext{
${ }^{19}$ It is worth mentioning that even if $\theta$ is considered to be a negative function of humanitarian aid, to reflect the substitution in the fraction of parental expenditures on children's health, the ambiguity of aid's impact on $\tilde{n}$ and $\tilde{\varepsilon}$ is futher reinforced.
} 
In the next subsection, we explore the sensitivity of our findings to the consideration of an additional type of aid along the lines of Azarnert (2008): per child monetary aid.

\subsection{Sensitivity Test}

Assume now that on top of aid per adult individual, $A^{a}$, and in kind aid per child, $A^{f}$, each household receives an amount of aid proportional to the number of children, $A^{c} .{ }^{20}$ Therefore total monetary aid is represented by $A^{a}+A^{c} n_{t+1}$, which as indicated earlier is measured in units of labor income. This means that in accordance to equation (3), monetary aid per child is

$$
A^{c}=c \alpha_{t+1} w_{t+1}, \quad c \in(0,1) .
$$

This consideration, and following the steps outlined in Appendix A, yields the following solutions for fertility, child rearing time, and per capita growth respectively:

$$
\begin{gathered}
\tilde{n}=\frac{\eta_{N}(1-\nu)(1+a)}{\left[\theta p\left(A^{f}\right)-c\right]\left[1+\eta_{N}(1-\nu)\right]}, \\
\tilde{\varepsilon}=\Lambda \frac{\left[\theta p\left(A^{f}\right)-c\right]\left[1+\eta_{N}(1-\nu)\right]}{p\left(A^{f}\right) \eta_{N}(1-\nu)(1+a)}, \\
1+\gamma=\theta\left(A^{f}\right)\left\{\Lambda \frac{\left[\theta p\left(A^{f}\right)-c\right]\left[1+\eta_{N}(1-\nu)\right]}{p\left(A^{f}\right) \eta_{N}(1-\nu)(1+a)}\right\}^{\nu} .
\end{gathered}
$$

The following assumption must be imposed to ensure positive values for these variables:

Assumption 2: $p\left(A^{f}\right)>c / \theta$.

This implies that the fraction of income received as monetary per child assistance be small compared to health spending on caring for each child.

In line with Azarnert (2008), equations (16)-(18) show that monetary per child aid $c$ increases fertility, decreases parent's investment on the health of their offspring by reducing child rearing time, and decreases output growth. At the same time, however, these equations demonstrate the validity of our main findings as to the ambiguity of the impact of total humanitarian aid. Now also note that total aid has an ambiguous effect on adult's child rearing time as well. The introduction of monetary aid proportional to the number of born children induces parents to increase their child rearing time as their expected (monetary) gain for every born child that survives rises. ${ }^{21}$

The analytical results, therefore, leave open the question as to the effects of humanitarian aid on fertility and growth. It is possible that one of the opposing effects

\footnotetext{
${ }^{20}$ Note that this type of aid is not given for every surviving child but for each born child to enhance their probability of survival.

${ }^{21}$ If instead, monetary aid $c$ was given for every surviving child, then the results would be similar to our benchmark findings except for the need of the assumption $c<\theta$.
} 
dominates the other so that aid has a non-zero (fertility and/or growth) effect. But it is equally plausible that the two effects exactly offset each other so that humanitarian aid does not have any impact at all. These are the issues that we try to shed some light on in the next section with the empirical evaluation of these effects.

\section{Evidence}

Our aim is to examine the effects of humanitarian aid transfers on the rates of fertility and economic growth. Although an investigation of the growth effects of aid is by no means novel, there has only been limited work on the effects of humanitarian aid. ${ }^{22}$ Furthermore, there has not been to our knowledge a systematic examination of the impact of humanitarian aid on fertility nor a joint consideration of its effects on both fertility and growth. In this section we offer an empirical investigation that combines these two issues.

\subsection{Estimation Strategy and Data}

The examination of the effects of humanitarian aid, first requires the classification of aid flows into humanitarian and non-humanitarian transfers. ${ }^{23}$ This classification follows Clemens et al. (2004), who disaggregate aid flows into three types - short-impact aid, long-impact aid, and humanitarian aid, and Neanidis and Varvarigos (2009), who divide aid into productive and humanitarian (pure) transfers. Given our focus on humanitarian aid, these two studies offer a natural benchmark for the construction of this type of flows. We will, however, also consider different proxies of humanitarian aid transfers below.

Using the OECD's Creditor Reporting System (CRS), which reports aid commitments by purpose, Table B1 in Appendix B describes the classification of aid flows into the categories under consideration. Naturally, humanitarian aid flows represent developmental and emergency food aid, and distress and reconstruction relief. An important issue is that all these categories of aid have elements of both in kind transfers and cash payments. Given that the data do not distinguish between in kind and cash transfers, we cannot control separately for their effects as represented by $A^{f}$ and $A^{a}$ in the theoretical model. The idea is, as they are by definition merged in the data, to examine whether they jointly have a non-zero effect on fertility or growth. If so, then this would be an indication that the effect of one type of aid (in kind or cash) dominates the other as described in our theory model.

\footnotetext{
${ }^{22}$ For the most influential studies in the literature see the introductory section.

${ }^{23}$ Although we cannot think of a type of aid not being humanitarian in nature, for the purpose of distinguishing humanitarian aid from the rest of aid transfers, we label remaining aid as "nonhumanitarian". In the literature it is most commonly referred to as "productive" aid. See Clemens et al. (2004) for a detailed discussion on the latter category of aid.
} 
Table B2 presents the methodology that has been followed in order to obtain proxies for the two types of aid flows. This requires the use of the OECD's Development Assistance Committee (DAC) database, which includes data on total ODA (Official Development Assistance) gross disbursements. As made clear in Clemens et al. (2004), the reason we construct our humanitarian and non-humanitarian aid proxies by using the CRS disaggregated aid commitments instead of the DAC disaggregated aid disbursements is the lack of data of the latter database prior to 1990. As such, our measures imply that the fraction of disbursements in the two aid categories in a given period is equal to the fraction of commitments in each category in that period. ${ }^{24}$

Consistent with our theoretical analysis which unveils the effects of humanitarian aid on both fertility and growth, we employ an empirical specification that corresponds to these considerations. For this reason, we estimate two equations corresponding to the fertility equation (12) and the growth equation (14), respectively. These two represent the reduced form equations of our model and are estimated independently of each other. However, we also consider their structural relationship as this is identified by equations (12) and (A15) and estimate them jointly as a system of equations where the rate of fertility appears as a determinant in the growth equation.

Given the above, our benchmark fertility and growth regression model is

$$
\begin{array}{r}
n_{i t}=\alpha_{0}+\beta_{1} A i d_{i t}^{H}+\beta_{2} A i d_{i t}^{r}+\sum_{l=1}^{m} \gamma_{l} X_{l, i t}+\sum_{j=1}^{n} \delta_{j} D_{j, i t}+\mu_{i}+\nu_{t}+\varepsilon_{i t}, \\
g_{i t}=\alpha_{1}+\lambda_{1} A i d_{i t}^{H}+\lambda_{2} A i d_{i t}^{r}+\sum_{k=1}^{q} \zeta_{k} Z_{k, i t}+\sum_{j=1}^{n} \psi_{j} D_{j, i t}+\mu_{i}+\nu_{t}+u_{i t},
\end{array}
$$

where the notation for equation (19) is as follows: $n_{i t}$ denotes the rate of fertility in country $i$ at time $t, A_{i} d_{i t}^{H}$ represents gross disbursements of humanitarian aid (\% of GDP), $A i d_{i t}^{r}$ is gross repayments on aid (\% of GDP), and $\left\{X_{l, i t}\right\}_{l=1}^{m}$ represents a set of variables that are considered to be influential on fertility. ${ }^{25}$ These are the level of economic development, as measured by the country's initial per capita GDP (in logs), the infant mortality rate, the level of education, and the level of urbanization. ${ }^{26}$ In addition, we control for dummies that capture regional differences with the set $\left\{D_{j, i t}\right\}_{j=1}^{n}$ (East Asia and Sub-Saharan Africa). Finally, all regressions account for

\footnotetext{
${ }^{24}$ Despite the popularity this technique has gained in the literature (Clemens et al. (2004), Neanidis and Varvarigos (2009)), we should make clear at the outset that our findings should be treated with caution as this method only offers an estimate of sector level aid disbursements that may entail errors the size of which we cannot assess.

${ }^{25}$ As shown in Table B2, the identity that determines gross repayments on aid is $A_{i d_{i t}^{G r o s s}}=A i d_{i t}^{N e t}+$ $A i d_{i t}^{r}$. The decision to use in our specification gross aid disbursements and gross aid repayments instead of net aid disbursements, is based on the consideration that aid repayments possibly have a different association with fertility and growth than aid disbursements. That is, we prefer to test for it rather than impose it. We do examine, however, the robustness of our findings with the use of net aid disbursements as well.

${ }^{26}$ See Angeles (2010) for a detailed discussion on the choice of these variables.
} 
common deterministic trends by incorporating dummies for the different time periods, $\nu_{t}$, and control for unobserved country-specific effects with country dummies, $\mu_{i}$, while $\varepsilon_{i t}$ is the error term.

In equation (20) except for $g_{i t}$ which denotes the growth rate of per capita real GDP and $\left\{Z_{k, i t}\right\}_{k=1}^{q}$ which represents a vector of variables that have been identified in previous growth studies to explain a substantial variation in the data, the rest of the variables are common to equation (19). The explanatory set $\left\{Z_{k, i t}\right\}_{k=1}^{q}$ includes the logarithm of initial per capita GDP, an indicator of institutional quality from the International Country Risk Guide, indicators of fiscal (budget balance), monetary (inflation), and trade (Sachs-Warner openness) policies, M2-to-GDP as a proxy for the development of the financial system, the fraction of land in the tropics indicating the idiosyncrasy of these locations, and dummies that control for the occurence of civil wars. The fertility rate is also included in the set when we simultaneously estimate equations (19) and (20). ${ }^{27}$

The coefficient estimates of $\beta_{1}$ and $\lambda_{1}$ will illustrate whether humanitarian aid has a significant effect on fertility and growth, and if so, the sign of the effect. Of course, it is possible that either or even both of these estimates do not statistically impact upon the dependent variables. In this case, we will take the finding as evidence of the offseting effects of humanitarian aid as these have been illustrated in the theory section.

We use five alternative econometric procedures to estimate equations (19) and (20). The first two are standard panel regressions, with the first controlling for time dummies and the second for both time and country-specific effects. The latter technique is superior to the inclusion of regional dummies as it allows every country in the sample to be treated differently. At the same time, however, it should be noted that it is not free of problems given that it may exacerbate a measurement error by removing a significant portion of the variation in the explanatory variables.

The other three estimation procedures are based on techniques that address potential endogeneity of the right-hand-side variables. Of these, the first two are dynamic GMM estimations that control for the endogeneity of all the regressors, and the third is a joint estimation of equations (19) and (20) in a system that considers only the endogeneity of the fertility rate in the growth equation (3SLS). The two dynamic procedures are the difference-GMM estimator developed by Arellano and Bond (1991) and the system-GMM estimator of Blundell and Bond (1998). The endogenous variables in the difference-GMM estimator are instrumented with lags of their levels, while systemGMM employs a richer set of endogenous instruments, treating the model as a system of equations in first-differences and in levels. In the latter, the endogenous variables in the first-difference equation are instrumented with lags of their levels as in differenceGMM, whilst the endogenous variables in the level equations are instrumented with lags of their first differences. Although these techniques have been popularized in

\footnotetext{
${ }^{27}$ All these variables are commonly used as controls of growth in the aid-growth literature. Their definition and sources can be found in Table B2.
} 
the aid-growth literature by Dalgaard et al. (2004) and Roodman (2004), they do have their limitations. Difference-GMM is susceptible to a weak-instruments problem because lagged levels may not be highly correlated with their first-differences, while system-GMM requires the instruments of the level equation to be orthogonal to the country-specific effects. Given their limitations, we choose to utilize both even though system-GMM has been found to produce less biased estimates than its difference counterpart (Hayakawa (2007)).

Another difficulty associated with the two dynamic GMM estimators relates to the choice of the number of lags of the endogenous variables used as instruments. This is an important issue raised by Roodman (2004, 2009) who shows a number of findings to be fragile to that choice. To enhance the robustness of our results, we estimate our model with various sets of lags. We initially use an unrestricted number of lags, starting at a lag length of two, and thereafter reduce the length of the maximum lags to four and three. This allows us to restrict the number of instruments to be smaller than the number of countries in the regression. ${ }^{28}$ For additional robustness, we do this either by directly reducing the number of lags or by collapsing the instrument set to create one instrument for each variable and lag distance (see Angeles and Neanidis (2009)).

Both the GMM approaches we use are checked for the validity of the instruments by applying two specification tests. The first test is the Hansen (1982) J-test of overidentifying restrictions which we use to examine the exogeneity of the instruments. This test is consistent in the presence of both heteroscedasticity and autocorrelation of any pattern. ${ }^{29}$ To avoid dynamic panel bias we instrument for regressors that are not strictly exogenous. These include all the right-hand-side variables in equations (19) and (20) except for the three location dummy variables. The second test is the Arellano and Bond (1991) test for serial correlation, the existence of which can cause a bias to both the estimated coefficients and standard errors. Given that first-differencing induces first-order serial correlation in the transformed errors, the appropriate check relates only to the absence of second-order serial correlation. To deal with any remaining serial correlation, we use clustered standard errors at the country level where appropriate.

Turning on to the data, we use a panel of 66 countries (a list of which is given in Appendix B) for the period 1973-2007, where the beginning of the period is restricted by the availability of the OECD reports on aid commitments (CRS). We follow the standard approach of constructing 4-year period averages (1973-75, 1976-79, 1980$1983, \ldots, 2004-2007)$ so as to minimise business cycle effects. This implies a maximum sample size of 594 observations, though we end up working with an unbalanced panel of 316 and 268 observations for equations (19) and (20) respectively because of missing data. The data on aid come from the OECD's DAC and CRS databases, while most of the rest of the data are from the World Bank's World Development Indicators. Details

\footnotetext{
${ }^{28}$ As pointed out by Roodman (2004), an excessive number of instruments can result in overfitting of the instrumented variables, thereby biasing the results towards those of the OLS.

${ }^{29}$ Failure of the null hypothesis suggests that the set of instruments is incomplete implying omitted variables bias.
} 
on the description and the sources of the variables can be found in Appendix B, Table B2. Table 1 presents some summary statistics of the data from where it is interesting to note that humanitarian aid represents slightly more than 10 percent of total aid flows. ${ }^{30}$

\subsection{Main Findings}

We begin our investigation by estimating equations (19) and (20) independently of each other with the two versions of fixed-effects and the two dynamic GMM procedures. Then, we allow for a simultaneous estimation of both equations with 3SLS using the sets of control variables described above. Recall that according to the theoretical mechanisms of the preceding section, the effect of humanitarian aid on fertility and growth could go in any direction. Our benchmark findings are presented in Table 2.

Starting with the fertility equation, the fixed time-effects regression in column (1) shows that fertility is positively influenced by infant mortality and location in SubSaharan Africa and negatively by education. At the same time, the level of a country's development, the degree of urbanization, and being situated in East Asia do not seem to matter. These findings are in line with Angeles (2010) and the contributions of the unified growth literature with regard to the process of demographic transitions, which stresses the importance of mortality rates (Kalemli-Ozcan (2003) and Azarnert (2006)) and education (Becker (1960), Barro and Becker (1989), Galor and Weil (2000)). Turning to the variable of our immediate concern, humanitarian aid appears not to have a significant effect on fertility. This is consistent with our theoretical illustration as far as the two opposing effects of in kind and monetary aid (either per adult or per born child) on fertility cancel out. This finding, however, contrasts Azarnert (2008) who proposes a positive effect.

Moving to the growth regression, the variables included in sets $Z_{k}$ and $D_{j}$ are supportive of the general findings in the literature. Specifically, having a higher institutional quality indicator, a more open oriented trade policy, and being situated in East Asia are conducive to faster economic growth. A higher inflation rate and being located in the tropics and in Sub-Saharan Africa, on the other hand, are associated with slower growth. In addition, there is no evidence of the importance of the financial sector, of fiscal discipline, of a recent internal conflict, and of conditional convergence. Finally, humanitarian aid appears to exert a positive effect on growth, albeit only significant at the 10 percent level. This result provides mild support to the dominance of

\footnotetext{
${ }^{30}$ Even though the average size of humanitarian aid in our sample represents 0.439 percent of the recipient country's GDP, this figure has not remained stable over each of the four decades that span our coverage period (1973-1980, 1981-1989, 1990-1998, 1999-2007). Humanitarian aid has been above average in the first decade (0.596), then dropped for the following two decades $(0.439$ and 0.257 respectively), and then picked up in the last decade $(0.480)$. The most generous providers of humanitarian aid among the donors, in absolute amounts transfered, include the United States (0.36), the European Commission (0.21), the United Kingdom (0.06), the Netherlands (0.04), and Japan (0.04) - the share of each country's humanitarian aid transfers in total humanitarian aid flows in parentheses.
} 
in kind aid on the health status of surviving children compared to per adult aid that reduces the child-rearing time adults allocate to their children. This, in turn, translates into higher productivity during adulthood and higher growth.

In column (2), the inclusion of country fixed-effects in addition to the time-effects, changes a few of the findings. Now the only significant contributor to higher fertility are higher rates of mortality. Similarly, in the growth regression we observe the significance of conditional convergence effects and of fiscal discipline effects in addition to the effects of inflation. All remaining regressors are now statistically insignificant, including humanitarian aid in both of the equations.

One possible drawback of the results presented thus far is that they may be biased by the endogeneity of some of the regressors. To overcome such a problem, the following three columns present results that control for reverse causality. Columns (3) and (4) depict the dynamic GMM regressions while column (5) the 3SLS regression with the instrumented variables appearing in bold type. In all of them, a consistent finding is the positive impact of mortality on fertility and the zero effect of humanitarian aid on economic growth. Moreover, the two GMM regressions indicate a negative effect of humanitarian aid on fertility significant at the 10 percent level, while the 3SLS estimation also unveils a diminishing effect of fertility on growth at the same level of significance. The rest of the explanatory variables in both regressions are less robust as they become statistically insignificant as we move between the three estimations.

The specification tests in Table 2 as expressed by Hansen's (1982) J-statistic, which examines the validity of the instruments in columns (3) and (4), cannot reject the hypothesis that the instruments are uncorrelated with the error term at a normal confidence level. ${ }^{31}$ Additionally, the Arellano-Bond (1991) test rejects the hypothesis of no second-order serial correlation in the error term in both regressions (4) at least at the 5 percent level.

The final point to note from our benchmark findings in Table 2 is that our variable of interest seems to have a statistically zero effect on both fertility and growth highlighting the offseting effects of humanitarian aid described in the theory section. If there is any indication of a non-zero effect, this appears to be mildly negative with regard to fertility, implying that humanitarian aid may work toward reducing population growth. The aim of the following section is to investigate the robustness of our findings in a more detailed manner.

\subsection{Robustness of Main Findings}

A few recent studies in the aid-growth literature (see Easterly (2003), Roodman (2004, 2009)) have demonstrated that most of the empirical results are sensitive and suggest the examination of their broader applicability. In this regard, we investigate in this section the robustness of our findings by re-running the regressions under various mod-

\footnotetext{
${ }^{31}$ Note that in these estimations we have used all the available lagged values as instruments starting from the second lag and reduced the number of instruments with the "collapse" command in Stata.
} 
ifications. These include alternative proxies for humanitarian aid, different measures of fertility, different instrument lag structures in the two dynamic GMM procedures, changes in regression specifications, and the modelling of non-linear aid-interaction effects. As will be shown, our basic findings survive all of these tests pointing to the zero effect of humanitarian aid.

\subsubsection{Alternative Humanitarian Aid Proxy}

As explained before, in line with the literature, our measure of humanitarian aid includes developmental food aid, emergency food aid, other emergency and distress relief, and reconstruction relief. This proxy may not be the best, however, since it ignores aid offered for medical or health reasons and aid offered to support the agricultural sector. In our theoretical model, health aid along with food aid have been influential to the probability of children survival to adulthood, whereas agriculture-related aid can be expected to augment food security and accessibility to food. At the same time, this definition includes reconstruction relief aid which may not be directly related to fertility as it is mainly used to support short-term construction work after an emergency.

We take up this issue and offer alternative proxies for humanitarian aid that account for the above considerations. First, we augment the original measure of humanitarian aid with health aid and then with both health and agriculture aid to consider a broader definition of aid. Then, we treat the original proxy of humanitarian aid separately from health and agriculture aid as we add each of them in the same regression to test for potentially different effects. Finally, we exclude the category of reconstruction relief from the original proxy of humanitarian aid and then control separately for health and agriculture-related aid transfers. Note that, as in the case of the original measure of humanitarian aid, health and agriculture-related aid represent a mix of both in kind and cash transfers. As such, it is not clear from the outset in which way these aid categories will influence fertility and growth.

Table 3 presents the estimates of these specifications. ${ }^{32}$ Columns (1) and (2) augment humanitarian aid with health aid and both health and agriculture aid, respectively. The results of both columns point to a zero effect of humanitarian aid on both fertility and growth, offering support to our main findings. The outcomes do not change when we include separately in the regression humanitarian aid, health aid, and agriculture aid as columns (3) and (4) indicate. In a similar way, columns (5) and (6) show that our findings survive the exclusion of reconstruction relief from the measure of humanitarian aid and the simultaneous inclusion of health and agriculture aid transfers as regressors. Given these, we conclude that our findings are not conditional on the proxy for humanitarian aid.

\footnotetext{
${ }^{32}$ Even though regression results are based on the fixed effects technique that controls for both country and time effects, the estimated coefficient of humanitarian aid is qualitatively the same when we use the rest of the techniques outlined in Table 2.
} 


\subsubsection{Alternative Fertility Measure}

In all preceding analysis we have used total fertility rate as our preferred measure of fertility. There are, however, a few alternative measures related to fertility used in the literature. These are the net fertility rate which is adjusted by the rate of mortality, the crude birth rate, the population growth rate, and the total fertility rate from a different source (United Nations) compared to the original variable (World Bank). ${ }^{33}$ To reflect on the choice of the fertility variable, and as a basis of comparison, we repeat our benchmark regression analysis by using each of the above variables instead. The results of these regressions are shown in Table 4. The use of the alternative fertility measures does not change our conclusions in any meaningful way as humanitarian aid continues to have a statistically insignificant impact on both fertility and growth. As before, we find the fertility-related variable to decrease growth in a statistically significant degree.

\subsubsection{Alternative Instrument Lag Structure}

Our dynamic GMM estimations have so far been based on the maximum number of lagged values used as instruments for the potentially endogenous explanatory variables. At the same time, we have used the "collapse" option in order to keep the number of instruments to a low level. We now take a different avenue and limit the number of instruments in an alternative way. As before, we start from the second lag and while originally allow for all possible lags of the endogenous variables as instruments, we then limit the maximum number of lags to four, and then to three. In this way, we can address the concerns raised by Roodman $(2004,2009)$ as to lag structure considerations.

The first three sets of columns in Table 5 refer to the difference-GMM estimations, while the following three sets present the system-GMM results. The effects of humanitarian aid are in line with our earlier findings. The only exception is that the negative effect of aid on fertility now appears to be robust only in the difference-GMM regression and significantly so at the 5 percent level for two of the regressions. We also observe that the specification tests confirm the validity of the instruments and the absence of second-order serial correlation at the 5 percent level. Therefore, we can conclude from this exercise that the choice of the instrument lag structure has no significant bearing on the coefficient estimates of humanitarian aid. ${ }^{34}$

\footnotetext{
${ }^{33}$ To ensure an appropriate specification in the regression of the crude birth rate, we include the crude death rate as a determinant. Also, we calculate the net fertility rate by adjusting for the infant mortality rate (which we then exclude from the regression), while the result is also robust to the consideration of the under-5 child mortality rate.

${ }^{34}$ The estimated coefficient of humanitarian aid is qualitatively the same even when we use the "collapse" option to further reduce the number of instruments.
} 


\subsubsection{Alternative Specifications and Aid Interaction Effects}

Although the variables included in vectors $X_{l}$ and $Z_{k}$ identify regressors that have been found relevant in the fertility and growth literatures, the sets are by no means exhaustive. To this extent, we examine the sensitivity of our findings by either replacing some variables with alternative measures or by expanding the two vectors with a number of additional control variables. The former include the use of trade openness measured by the size of trade (as fraction of GDP) in the growth regression instead of the Sachs-Warner trade policy indicator, and the replacement of infant mortality rates with life expectancy at birth in the fertility equation (Angeles (2010)). The extra control variables in the growth equation include life expectancy (Clemens et al. (2004)), black market premium and initial secondary school enrolment (Barro and Sala-i-Martin (1995)), while new variables common to both regressions include a dummy that proxies for the period immediately following a civil conflict (Collier and Hoeffler (2002)) and non-humanitarian (productive) aid (Clemens et al. (2004), Minoiu and Reddy (2009), Neanidis and Varvarigos (2009)). The results, presented in Table 6, are based on the joint estimation of the two equations with 3SLS. The estimated coefficient on humanitarian aid, however, remains unchanged when we use the rest of the techniques outlined in Table 2.

As can be seen, the replacement or inclusion of other variables in our model specifications do not alter our conclusions in any way. The coefficient on humanitarian aid is still found to be insignificant with regard to both growth and fertility. The additional controls have the expected sign, with life expectancy having a negative effect on fertility and the black market premium a negative effect on growth. Furthermore, the time period following a civil war leads to higher fertility (significant at the 10 percent level) reflecting the compensation process of parents to the loss of children during the war. This mechanism, known as the "replacement effect", has been traditionally explained by the demographic literature (see, for instance, Palloni and Rafalimanana (1999)). Finally, non-humanitarian aid is found to positively impact upon both fertility and growth. The latter of the effects complements the findings of Clemens et al. (2004), Minoiu and Reddy (2009), and Neanidis and Varvarigos (2009), while the former indicates the willingness of parents to have more children in the presence of aid flows directed to the support of the educational, social and capital infrastructure, and development needs of the general population. Although our theoretical model does not make any provision for the effects of this type of aid, the empirical findings imply an additional human - and a new physical - capital accumulation channel through which "productive" aid although increases the quantity of children also offers a quality extension of their livelihood.

Another set of checks we undertake is motivated by the observations that the impact of aid on growth exhibits diminishing returns or that it appears to be context-specific. For example, Hansen and Tarp (2001) and Clemens et al. (2004) find aid squared to have a negative effect on growth, while there is also evidence to suggest that the positive growth effect is limited in countries with a good macroeconomic policy envi- 
ronment (Burnside and Dollar (2000)), in countries outside the tropical climate zone (Daalgard et al. (2004)), and in time periods following a conflict but not immediately after (Collier and Hoeffler (2002)). At the same time, Azarnert (2008) supports that humanitarian aid in sub-Saharan Africa has a positive effect on fertility and a negative effect on growth as these countries have not yet experienced the demographic transition. Although most of the growth-related findings have been overturned by Angeles and Neanidis (2009) in the case of total aid flows, we wish to test the validity of our results when such considerations are taken into account with regard to humanitarian aid.

Our findings are summarised in Table 7. Column (1) modifies our regression specifications to allow for the squared effects of humanitarian aid, non-humanitarian aid, and aid repayments. As before, humanitarian aid has a zero effect while non-humanitarian aid has a positive effect in both equations, without any indication of diminishing returns. In columns (2), (3) and (4), the impact of humanitarian aid does not appear to be influenced by the policy environment, the consideration of climatic differences, and the timing of its distribution, respectively. ${ }^{35}$ Humanitarian aid directed to subSaharan Africa and high-fertility pre-demographic transition countries, however, does have an impact on fertility and growth as shown in columns (5) and (6). In particular, humanitarian aid provided to sub-Saharan African nations even though it does not influence fertility, it reduces economic growth (and increases economic growth to the rest of the recipients). At the same time, high-fertility countries that receive this type of aid experience an increase in their fertility rates with no effect on economic growth. These findings suggest that parents in sub-Saharan Africa respond to higher humanitarian aid by lowering the child-rearing time they allocate to their offsprings, which reduces their health status and productivity as adults. In addition, in high-fertility countries humanitarian aid reduces the cost of having children pointing to a different fertility effect compared to countries that underwent the demographic transition, as documented by Azarnert (2008). Overall, therefore, we conclude that except for the pre-demographic transition countries our findings are not influenced by non-linear and aid interaction effects.

Finally, we further explore the validity of our findings to the exclusion of outlier observations, a different measure of aid, and an alternative period averaging. Even though we do not report the results to save space, when we exclude the outliers identified by the Hadi (1992) procedure we observe that the results remain unchanged. Similarly, our findings are in place when we use net aid disbursements - as most of the studies in the related literature use - instead of gross aid disbursements in the calculation of humanitarian aid transfers. Lastly, our results remain unaffected when we consider an alternative time period averaging of nine-year intervals that correspond to each decade (1973-1980, 1981-1989, 1999-2007) even though Easterly (2003) and Roodman (2004)

\footnotetext{
${ }^{35}$ The policy environment is proxied by the Sachs-Warner policy indicator. Results do not change even when we use an interaction term between humanitarian aid and a post-conflict dummy variable that accounts for two periods after the elapse from war.
} 
have shown that different periodizations can significantly alter the results of the most prominent empirical studies. The results of all these extra sensitivity tests are available upon request.

\section{Concluding Remarks}

Our aim in this paper has been to study how humanitarian aid may impact on demographic transition and economic growth. It has been motivated by a recent article by Azarnert (2008) who supports that humanitarian aid may work against its goals of diminishing population growth and fostering economic development. Our theoretical results, however, indicate that the effects of humanitarian aid are not that straightforward as they unveil significant ambiguity. The empirical investigation illustrates that aid does not have a significant impact on fertility and growth (except for the pre-demographic transition countries), providing support to the two conflicting effects of humanitarian aid outlined in our theory model.

The theoretical model presents a two-period OLG economy where reproductive agents live (at most) for two periods: childhood and adulthood. Agents face a nonzero probability of death in childhood, which is decreasing in the amount of food aid consumed. On top of this non-monetary type of aid, each adult individual receives a permanent flow of monetary aid which along with the labour income is used to finance individual consumption and spending on each child's health. In addition to working, adults allocate their time to leisure and child rearing activities of surviving children. Following the literature, the health status of a child depends on the income spent on goods for each child, the amount of in kind aid, the parent's health status, and the time allocated by their parent to rearing them, while the health status of adults exhibits "state dependence" in the sense that it depends linearly on their health status in childhood. Therefore, although fertility choices are endogenous, the model abstracts from human capital accumulation so that life expectancy is directly related to health status rather than human capital arising from educational choices.

The foregoing discussion suggests that, when assessing the impact of humanitarian aid on health outcomes and growth, it is important to account both for the direct effects (in kind aid) and for the indirect effects that may operate through time allocation (monetary aid). If indeed aid allows for a more efficient use of time, understanding what households do with these time savings becomes critical to health and growth. This is because individuals may consider not only allocating more "raw time" to market work as an alternative, but also increasing time spent in home production and caring for children's health. This latter activity would affect health status in adulthood, and therefore productivity, wages, and growth.

The effect of humanitarian aid on both the rates of fertility and growth of per worker output is found to be ambiguous. On the one hand, in kind aid, by increasing the probability of survival from childhood to adulthood, has a negative effect on fertility, while on the other, monetary per-adult aid increases fertility by reducing the "quantity 
cost" of children. In a similar way, in kind aid, by directly enhancing the health status of surviving children, has a positive effect on growth while at the same time monetary aid reduces the child-rearing time of adults. This in turn, lowers the health status of both children and adults, and subsequently the rate of economic growth. Given the ambiguity of the theoretical analysis as to the effects of humanitarian aid, we resort to an empirical investigation.

The empirical evidence is obtained by applying standard regression techniques to trace the impact of humanitarian aid on fertility and growth. The empirical methodology considers both reduced form estimations and joint estimations of the system of the two equations. Our results suggest that humanitarian aid has on average a zero impact on both the rate of fertility and the rate of output growth, implying that the two conflicting effects of humanitarian aid outlined by our theoretical illustration fully offset each other. The sole exception applies to countries characterized by high fertility rates where humanitarian aid is shown to raise fertility. Our results are robust to a wide range of sensitivity tests and efforts to control for simultaneity bias.

A natural extension of the theoretical analysis would be to model the effects of nonhumanitarian or productive aid. As the empirical section suggests, the positive effects of this type of aid on fertility and growth contrast the effects of humanitarian aid. The positive impact on fertility could be an outcome of improvements in living conditions as these emerge from the investment of aid on health, education, and infrastructure services provided by the government. This could induce parents to spent a smaller fraction of their income on their children's health as now the government contributes to this expense. This, in turn, would lead parents to optimally choose a higher number of children. This increase in fertility, however, will not cause a decline in growth. On the contrary, the improved quality of provided public services would directly affect the population health status, which, if marginally significant, would increase productivity and growth. 


\section{References}

Agénor, P-R. 2006. "Public Capital, Health Persistence, and Poverty Traps," Working Paper No. 115, Centre for Growth and Business Cycle Research, University of Manchester.

Almond, D. 2006. "Is the 1918 Influenza Pandemic Over? Long-Term Effects of In Utero Influenza Exposure in the Post-1940 U.S. Population," Journal of Political Economy, $114,672-712$.

Angeles, L. 2010. "Demographic Transitions: Analyzing the Effects of Mortality on Fertility," Journal of Population Economics, 23(1), 99-120.

Angeles, L., and Neanidis, K.C. 2009. "Aid Effectiveness: The Role of the Local Elite," Journal of Development Economics (forthcoming).

Arellano, M., and Bond, S. 1991. "Some Tests of Specification for Panel Data: Monte Carlo Evidence and an Application to Employment Equations. Review of Economic Studies, 58, 277-297.

Azarnert, L.V. 2006. "Child Mortality, Fertility and Human Capital Accumulation," Journal of Population Economics, 19, 285-297.

Azarnert, L.V. 2008. "Foreign Aid, Fertility and Human Capital Accumulation," Economica, 75, 766-781.

Ball, R., and Johnson, C. 1996. "Political, Economic and Humanitarian Motivations for PL 480 Food Aid: Evidence from Africa," Economic Development and Cultural Change, 44, 515-547.

Barker, D.J.P. 1998. Mothers, Babies and Health in Later Life. 2nd ed. Edinburgh, UK: Churchill Livingston.

Barro, R. J., and Becker, G.S. 1989. "Fertility Choice in a Model of Economic Growth," Econometrica, 57, 481-501.

Barro, R.J., and Sala-i-Martin, X. 1995. Economic Growth, McGraw Hill, New York.

Becker, G.S. 1960. "An Economic Analysis of Fertility," in Demographic and Economic Change in Developed Countries, National Bureau Conference Series N.10, Princeton University Press.

Becker, G.S. 2007. "Health as Human Capital: Synthesis and Extensions," Oxford Economic Papers, 59, 379-410.

Bezuneh, M., Deaton, B., and Zuhair, S. 2003. "Food Aid Disincentives: The Tunisian Experience," Review of Development Economics, 7(4), 609-621.

Bhattacharya, J., and Qiao, X. 2007. "Public and Private Expenditures on Health in a Growth Model," Journal of Economic Dynamics and Control, 31, 2519-35.

Blackburn, K., and Cipriani, G.P. 2002. "A Model of Longevity and Growth," Journal of Economic Dynamics and Control," 26, 187-204.

Bloom, D., and Canning, D. 2005. "Schooling, Health, and Economic Growth: Reconciling the Micro and Macro Evidence," unpublished, Harvard School of Public Health. 
Blundell, R., and Bond, S. 1998. "Initial Conditions and Moment Restrictions in Dynamic Panel Data Models," Journal of Econometrics, 87, 115-143.

Brown, L., and Haddad, L. 1995. "Time Allocation Patterns and Time Burdens: A Gendered Analysis of Seven Countries," International Food Policy Research Institute, Washington DC.

Burnside, C., and Dollar, D. 2000. "Aid, Policies, and Growth," American Economic Review, 90, 847-868.

Case, A., Fertig, A., and Paxson, C. 2005. "The Lasting Impact of Childhood Health and Circumstance," Journal of Health Economics, 24, 365-89.

Caulfield, L.E., de Onis, M., Bloessner, M., and Black, R.E. 2004. "Undernutrition as an Underlying Cause of Child Deaths Associated with Diarrhea, Pneumonia, Malaria, and Measles," American Journal of Clinical Nutrition, 80,193-98.

Center for Global Development Brief, 2007. "Millions Saved: Proven Successes in Global Health," Center for Global Development, Washington DC.

Cervellati, M., and Sunde, U. 2005. "Human Capital Formation, Life Expectancy, and the Process of Economic Development," American Economic Review, 95, 1653-72.

Chakraborty, S. 2004. "Endogenous Lifetime and Economic Growth," Journal of Economic Theory, 116, 119-37.

Chatterjee, S., Sakoulis, G., and Turnovsky, S.J. 2003. "Unilateral Capital Transfers, Public Investment, and Economic Growth," European Economic Review, 47, 10771103.

Clemens, M.A., Radelet, S., and Bhavnani, R. 2004. "Counting Chickens When They Hatch: The Short-Term Effect of Aid on Growth," Working Paper No. 44, Center for Global Development.

Collier, P., and Dehn, J. 2001. "Aid, Shocks, and Growth," Working Paper No. 2688, World Bank.

Collier, P., and Hoeffler, A. 2002. "Aid, Policy and Growth in Post-Conflict Societies," Working Paper No. 2902, World Bank.

Collier, P., Hoeffler, A., and Sambanis, N. 2006. "The Collier-Hoeffler Model of Civil War Onset and the Case Study Project Research Design, Understanding Civil War, Vol. 2: Europe, Central Asia, and Other Regions." Eds. Collier P., and Sambanis, N., World Bank.

Cutler, D.M., Deaton, A., and Lleras-Muney, A. 2006. "The Determinants of Mortality," Journal of Economic Perspectives, 20, 97-120.

Daalgard, C., Hansen, H., and Tarp, F. 2004. "On the Empirics of Foreign Aid and Growth," Economic Journal, 114(496), F191-F216.

De Waal, A., Taffesse, S., and Carruth, L. 2006. "Child Survival During the 2002-2003 Drought in Ethiopia," Global Public Health, 1(2), 125-132. 
Doucouliagos, H., and Paldam, M. 2008. "Aid-Effectiveness on Growth: A Meta Study," European Journal of Political Economy,24(1), 1-24.

Downey, G., Purdie, V., Schaffer-Neitz, R. 1999. "Anger Transmission from Mother to Child: A Comparison of Mothers in Chronic Pain and Well Mothers," Journal of Marriage and the Family, 61, 62-73.

Easterly, W. 2003. "Can Foreign Aid Buy Growth?" Journal of Economic Perspectives, $17,23-48$.

Easterly, W., Levine, R., and Roodman, D. 2004. "Aid, Policies, and Growth: Comment," American Economic Review, 94(3), 774-780.

Economides, G., Kalyvitis, S., and Philippopoulos, A. 2008. "Does Foreign Aid Distort Incentives and Hurt Growth? Theory and Evidence from 75 Aid-Recipient Countries," Public Choice, 134, 463-488.

Fogel, R.W. 1994. "Economic Growth, Population Theory, and Physiology: The Bearing of Long-Term Economic Processes on the Making of Economic Policy," American Economic Review, 84, 369-395.

Galor, O., and Weil, D.N. 2000. "Population, Technology, and Growth: From the Malthusian Regime to the Demographic Transition and Beyond," American Economic Review, 90, 806-28.

Grossman, M. 1972. "On the Concept of Health Capital and the Demand for Health," Journal of Political Economy, 80, 223-55.

Hadi, A.S. 1992. "Identifying Multiple Outliersin Multivariate Data," Journal of the Royal Statistical Society, Series B 54, 761-777.

Hansen, L. 1982. "Large Sample Properties of Generalized Methods of Moments Estimators," Econometrica, 50, 1029-1054.

Hansen, H., and Tarp, F. 2001. "Aid and Growth Regressions," Journal of Development Economics, 64(2), 547-570.

Hayakawa, K. 2007. "Small Sample Bias Properties of the System GMM Estimator in Dynamic Panel Data Models," Economics Letters, 95(1), 28-32.

Headey, D.D. 2007. "Geopolitics and the Effect of Foreign Aid on Economic Growth: 1970-2001," Journal of International Development, 20(2), 180-191.

Huff, H.B., and Jimenez, M. 2003. "The Food Aid Convention: Past Performance and Future Role within the New Global Trade and Development Environment," Paper presented at the International Conference on Agricultural Policy Reform and the WTO: Where are we Heading?, Capri, Italy.

Ilahi, N. 2000. "The Intra-Household Allocation of Time and Tasks: What have we Learned from the Empirical Literature?," Policy Research Report on Gender and Development No. 13, World Bank.

Kalemli-Ozcan, S. 2003. "A Stochastic Model of Mortality, Fertility, and Human Capital Investment," Journal of Development Economics, 70, 103-18. 
Kraak, V.I., Pelletier, D.L., Frongillo, E.A.Jr., and Rajabiun, S. 1999. "The Potential Role of Food Aid for AIDS Mitigation in East Africa: Stakeholder Views," Food and Nutrition Technical Assistance (FANTA) Project, Academy for Educational Development, Washington DC.

Larson, R.W., and Gillman, S. 1999. "Transmission of Emotions in the Daily Interactions of Single-Mother Families," Journal of Marriage and the Family, 61, 21-37.

Miquel-Florensa, J. 2007. "Aid Effectiveness: A Comparison of Tied and Untied Aid," Working Paper No. 3, Department of Economics, York University.

Minoiu, C., and Reddy, S.G. 2009. "Development Aid and Growth: A Positive Long-Run Relation," Quarterly Review of Economics and Finance (forthcoming).

Moav, O. 2005. "Cheap Children are the Persistence of Poverty," Economic Journal, 115, 88-110.

Neanidis, K.C., and Varvarigos, D. 2009. "The Allocation of Volatile Aid and Economic Growth: Theory and Evidence," European Journal of Political Economy,25(4), 447462.

Palloni, A., and Rafalimanana, H. 1999. "The Effects of Infant Mortality on Fertility Revisited: New Evidence from latin America," Demography, 36(1), 41-58.

Pelletier, D. L., Frongillo, E. A., and Habicht, J-P. 2003. "Epidemiologic Evidence for a Potentiating Effect of Malnutrition on Child Mortality," American Journal of Public Health, 83, 1130-33.

Plümber, T., and Neumayer, E. 2009. "Famine Mortality, Rational Political Inactivity, and International Food Aid," World Development, 37(1), 50-61.

Powdthavee, N., and Vignoles, A. 2008. "Mental Health of Parents and Life Satisfaction of Children: A Within-Family Analysis of Intergenerational Transmission of Well-Being," Discussion Paper No. 20, University of York.

Roodman, D. 2004. "The Anarchy of Numbers: Aid, Development, and Cross-Country Empirics," Working Paper No. 32, Center for Global Development.

Roodman, D. 2009. "A Note on the Theme of Too Many Instruments," Oxford Bulletin of Economics and Statistics, 71(1), 1358-158.

Smith, J.P. 2008. "The Impact of Childhood Health on Adult Labor Market Outcomes," Working Paper No. 2008-14, University College Dublin.

Strauss, J., and Thomas, D. 1998. "Health, Nutrition and Economic Development," Journal of Economic Literature, 36, 766-817.

Svensson, J. 2000. "When is Foreign Aid Policy Credible? Aid Dependence and Conditionality," Journal of Development Economics, 61, 61-84. 


\section{Appendix A}

\section{Technical Appendix}

Before solving the individual's maximization problem, rewrite equation ( 7 ) for $t+1$, as

$$
h_{t+1}^{C}=\theta\left(A^{f}\right)\left(h_{t+1}^{A}\right)\left(\varepsilon_{t+1}\right)^{\nu},
$$

and combine it with (8) to give

$$
h_{t+1}^{C}=\theta\left(A^{f}\right)\left(h_{t}^{C}\right)\left(\varepsilon_{t+1}\right)^{\nu} .
$$

Given that $p_{t+1}\left(A^{f}\right)=p\left(A^{f}\right)$, each individual maximizes

$$
\begin{gathered}
U_{t+1}=\ln c_{t+1}^{t}+\eta_{L} \ln \left(1-p_{t+1}\left(A^{f}\right) n_{t+1} \varepsilon_{t+1}\right) \\
+\eta_{N} \ln p_{t+1}\left(A^{f}\right) n_{t+1} h_{t+1}^{C},
\end{gathered}
$$

with respect to $c_{t+1}^{t}, \varepsilon_{t+1}$, and $n_{t+1}$, subject to (A1), (9), (10), as well as (3) and (5), which are combined and rewritten here for convenience:

$$
\left[1-\theta p\left(A^{f}\right) n_{t+1}\right] \alpha_{t+1} w_{t+1}-c_{t+1}^{t}+a \alpha_{t+1} w_{t+1}=0 .
$$

First-order conditions yield

$$
\frac{1}{c_{t+1}^{t}}=\lambda
$$

where $\lambda$ is the co-state variable associated with constraint (A3), together with

$$
\begin{gathered}
\frac{\eta_{L} p\left(A^{f}\right) n_{t+1}}{1-p\left(A^{f}\right) n_{t+1} \varepsilon_{t+1}}=\frac{\eta_{N} \nu}{\varepsilon_{t+1}} \\
\frac{\eta_{L} p\left(A^{f}\right) \varepsilon_{t+1}}{1-p\left(A^{f}\right) n_{t+1} \varepsilon_{t+1}}-\frac{\eta_{N}}{n_{t+1}}=-\frac{\theta p\left(A^{f}\right) \alpha_{t+1} w_{t+1}}{c_{t+1}^{t}} .
\end{gathered}
$$

Substituting the budget constraint (5) in (A6) yields

$$
\frac{\eta_{L} p\left(A^{f}\right) n_{t+1} \varepsilon_{t+1}}{1-p\left(A^{f}\right) n_{t+1} \varepsilon_{t+1}}-\eta_{N}=-\frac{\theta p\left(A^{f}\right)}{1-p\left(A^{f}\right) n_{t+1} \varepsilon_{t+1}+a} .
$$

Rewrite (A5) as

$$
\frac{\eta_{L} p\left(A^{f}\right) n_{t+1} \varepsilon_{t+1}}{1-p\left(A^{f}\right) n_{t+1} \varepsilon_{t+1}}=\eta_{N} \nu
$$

and substitute $(\mathrm{A} 8)$ in $(\mathrm{A} 7)$ to obtain

$$
\eta_{N}(\nu-1)=-\frac{\theta p\left(A^{f}\right)}{1-p\left(A^{f}\right) n_{t+1} \varepsilon_{t+1}+a},
$$


which when solved for $n_{t+1}$ yields

$$
\tilde{n}=\frac{\eta_{N}(1-\nu)(1+a)}{\theta p\left(A^{f}\right)\left[1+\eta_{N}(1-\nu)\right]}>0 .
$$

Substituting (A10) back in (A8), and after some simplification, yields

$$
\tilde{\varepsilon}=\Lambda \frac{1}{p\left(A^{f}\right) \tilde{n}}=\Lambda \frac{\theta\left[1+\eta_{N}(1-\nu)\right]}{\eta_{N}(1-\nu)(1+a)}>0,
$$

where

$$
\Lambda \equiv \frac{\eta_{N} \nu}{\eta_{L}+\eta_{N} \nu}<1
$$

This result implies that $\tilde{\varepsilon}=0$ if either $\eta_{N}=0$ (bearing children brings no utility) or $\nu=0$ (time spent in child rearing does not affect a child's health status). The reason is that in the model adult health is not valued per se, but only to the extent that it benefits children. Also note that from (A11) and (A12), it can be shown that $p\left(A^{f}\right) \tilde{n} \tilde{\varepsilon}<1$, given that $\Lambda<1$. Thus, leisure is positive in equilibrium. In addition, a necessary condition for (A3) can be derived from (A10), $1-\theta p\left(A^{f}\right) \tilde{n}>0$, as long as monetary aid is not too large: $a<1 / \eta_{N}(1-\nu)$.

Equations (A10) and (A11) have the following implications

$$
\begin{gathered}
\frac{d \tilde{n}}{d\left(A^{f}\right)}<0, \quad \frac{d \tilde{n}}{d a}>0, \\
\frac{d \tilde{\varepsilon}}{d\left(A^{f}\right)}=0, \quad \frac{d \tilde{\varepsilon}}{d a}<0 .
\end{gathered}
$$

Thus, an increase in in kind aid per child lowers the fertility rate $\tilde{n}$, while it has no effect on total time allocated to child rearing $\tilde{\varepsilon}$. Monetary per adult aid, on the other hand, increases fertility and reduces child rearing time.

The production function equation (6) implies that aggregate output per worker in $t+1$ is

$$
\frac{Y_{t+1}}{N_{t+1}}=B_{t+1}
$$

or equivalently, using (10) and the fact that in equilibrium $\alpha_{t+1}=B_{t+1}$,

$$
\frac{Y_{t+1}}{N_{t+1}}=h_{t+1}^{A}=\theta\left(A^{f}\right)\left(h_{t}^{A}\right)\left(\varepsilon_{t}\right)^{\nu}
$$

Finally, using $h_{t}^{A}=Y_{t} / N_{t}$, aggregate output per worker in $t+1$ becomes

$$
\frac{Y_{t+1}}{N_{t+1}}=\theta\left(A^{f}\right)\left(\varepsilon_{t}\right)^{\nu} \frac{Y_{t}}{N_{t}} .
$$


Using (A14), this implies that the balanced-growth rate of output per worker is

$$
1+\gamma=\theta\left(A^{f}\right)(\tilde{\varepsilon})^{\nu}=\theta\left(A^{f}\right)\left(\Lambda \frac{1}{p\left(A^{f}\right) \tilde{n}}\right)^{\nu},
$$

or equivalently, using (A11),

$$
1+\gamma=\theta^{(1+\nu)}\left(A^{f}\right)\left\{\Lambda \frac{\left[1+\eta_{N}(1-\nu)\right]}{\eta_{N}(1-\nu)(1+a)}\right\}^{\nu} .
$$

Equation (A15) implies that the model has no transitional dynamics; following a shock, the time adults allocate to child rearing must jump immediately to its new equilibrium value. It then follows from (A16) that the economy is always on its balanced growth path. From (A13) it is also clear that the health status of both adults and children, $h_{t}^{A}$ and $h_{t}^{C}$, grow at the same constant rate.

Equation (A16) has the following implications

$$
\frac{d(1+\gamma)}{d\left(A^{f}\right)}>0, \quad \frac{d(1+\gamma)}{d a}<0 .
$$

Thus, an increase in in kind per child aid increases the growth rate of per worker output, while monetary per adult aid has exactly the opposite effect. 


\section{Appendix B}

\section{Country and Data Appendix}

\section{Country Sample (66)}

Argentina, Belarus, Belize, Bhutan, Bolivia, Brazil, Bulgaria, Burkina Faso, Burundi, Cameroon, Chile, Colombia, Congo Dem. Rep., Congo Rep., Costa Rica, Cote d'Ivoire, Cyprus, Dominican Rep., Egypt, Estonia, Ethiopia, Gambia, Guatemala, Guyana, Haiti, Honduras, India, Indonesia, Iran, Israel, Korea Rep., Lesotho, Liberia, Madagascar, Malaysia, Mali, Malta, Mauritius, Mexico, Mongolia, Morocco, Nepal, Nicaragua, Pakistan, Panama, Paraguay, Peru, Poland, Romania, Rwanda, Senegal, Seychelles, Slovenia, Sri Lanka, Suriname, Syrian Arab Rep., Tanzania, Thailand, Togo, Tonga, Tunisia, Turkey, Uruguay, Yemen Rep., Zambia, Zimbabwe.

Table B1

Classification of aid flows

\begin{tabular}{|c|c|}
\hline Humanitarian aid " $H$ " & Non-humanitarian aid " $N$ " \\
\hline 520 Developmental Food Aid/ & 110 Education \\
\hline \multicolumn{2}{|l|}{ Food Security Assistance } \\
\hline 710 Emergency Food Aid & 120 Health \\
\hline 720 Other Emergency and Distress Relief & $\begin{array}{l}130 \text { Population Policies/Programmes } \\
\text { and Reproductive Health }\end{array}$ \\
\hline \multirow[t]{25}{*}{730 Reconstruction Relief } & 140 Water Supply and Sanitation \\
\hline & 150 Government and Civil Society \\
\hline & 160 Other Social Infrastructure and Services \\
\hline & 210 Transport and Storage \\
\hline & 220 Communications \\
\hline & 230 Energy Generation and Supply \\
\hline & 240 Banking and Financial Services \\
\hline & 250 Business and Other Services \\
\hline & 311 Agriculture \\
\hline & 312 Forestry \\
\hline & 313 Fishing \\
\hline & 321 Industry \\
\hline & 322 Mining and Mineral Resources \\
\hline & 323 Construction \\
\hline & 331 Trade Policy and Regulations \\
\hline & 332 Tourism \\
\hline & 410 General Environmental Protection \\
\hline & 420 Women in Development \\
\hline & 430 Other Multisectoral \\
\hline & 510 General Budget Support \\
\hline & 530 Other General Programme and Commodity \\
\hline & Assistance \\
\hline & 600 Action Relating to Debt \\
\hline & 920 Support to NGO's \\
\hline & 998 Unallocated/Unclassified \\
\hline
\end{tabular}

Note: The classification of aid into humanitarian/non-humanitarian follows Clemens et al. (2004) and Neanidis and Varvarigos (2009) at the three-digit level based on the OECD's CRS. 
Table B2

Variables description and sources

\begin{tabular}{l}
\hline \multicolumn{1}{c}{ Variable } \\
\hline Basic Set \\
GDP p.c. growth rate \\
Humanitarian and non- \\
humanitarian aid
\end{tabular}

Aid repayments
Initial p.c. GDP
Institutional quality

Inflation

Trade policy (Sachs-Warner)

M2/GDP

Budget balance

Tropical

Civil war

East Asia

Sub-Saharan Africa

Fertility rate

Infant mortality

Initial school

\section{Urban}

\section{Sensitivity Set}

Crude birth rate

Crude death rate

Net fertility rate

Population growth rate

Total fertility rate

\section{Trade}

Initial life expectancy

Black market premium

Post-conflict1 (Post-conflict2)

High-fertility countries
Annual percentage growth rate of GDP per capita based on constant local currency.

"Humanitarian" aid is the product across all donors, for each recipient, of "Total ODA (OA) Gross

Disbursements" from the online DAC database, Table 2a, with the elements of the CRS field "usd amount" classified as "H" in Table A1, divided by the sum of all aid in CRS field "Total ODA (OA) Commitments", multiplied by 100. "Non-humanitarian" aid is calculated in a similar way, according to the " $\mathrm{N}$ " classification in Table B1 ( $\%$ of GDP in current USD from WDI).

"Total ODA (OA) Gross" minus "Total ODA (OA) Net" ( $\%$ of GDP in current USD).

GDP per capita in constant 2000 USD for the first year of the period.

ICRGE indicator: average of corruption, bureaucratic quality and rule of law indicators that takes values between 0 and 10 .

Natural logarithm of $1+$ consumer price inflation rate.

Dummy variable that measures the degree of openness.

Money and quasi money ( $\%$ of GDP in current USD).

Overall budget balance, including grants ( $\%$ of GDP in current USD).

Dummy indicating tropical location.

Dummy that takes the value of 1 during a period of civil war.

Dummy indicating region.

Dummy indicating region.

Fertility rate (births per woman), total.

Mortality rate, infant (per 1,000 live births).

Gross ratio of total enrollment, regardless of age, to the population of the secondary school age group, for the first year of the period.

Urban population ( $\%$ of total) .

Birth rate, crude (per 1,000 people).

Death rate, crude (per 1,000 people).

As the total fertility rate is expressed in births per woman while the mortality rate is expressed in terms of 1,000 live births, an adjustment needs to be made to the rate of mortality in order to be expressed in terms of live births per woman: net fertility rate $=$ total fertility rate $-($ total fertility rate)*(mortality rate)/1000.

Population growth (annual \%).

Fertility rate (births per woman).

Sum of exports and imports (\% of GDP in current USD). Life expectancy at birth, total.

[(Parallel exchange rate/official exchange rate)-1]*100.

Dummy that takes the value of 1 one (two) period(s) after civil war has ended.

Dummy that takes the value of 1 for countries with a rate of fertility above the sample average of 4.22 .
World Bank, WDI

OECD, $D A C$ (online) and $C R S$ (online) based on Clemens et al. (2004) and Neanidis and Varvarigos (2009)

OECD, $D A C$ (online) and $W D I$

World Bank, WDI

Roodman (2004) and Political Risk Group

World Bank, WDI

Wacziarg and Welch (2003)

and Roodman (2004)

World Bank, WDI

World Bank, WDI

World Bank, Global

Development Network

Collier, Hoeffler, and Sambanis (2006)

World Bank

World Bank

World Bank, WDI

World Bank, WDI

World Bank, WDI

World Bank, WDI

World Bank, WDI

World Bank, WDI

World Bank, WDI based on own calculations.

World Bank, WDI

United Nations, Population

Division

World Bank, WDI

World Bank, WDI

World Bank, Global

Development Network

Collier, Hoeffler, and Sambanis (2006)

World Bank, WDI 
Table 1

Summary statistics

\begin{tabular}{lccccc}
\hline \multicolumn{1}{c}{ Variable } & Mean & Std. Dev. & Min & Max & Obs \\
\hline GDP p.c. growth rate & 1.76 & 3.26 & -12.36 & 14.02 & 268 \\
Humanitarian aid & 0.439 & 0.862 & 0 & 6.47 & 268 \\
Non-humanitarian aid & 3.66 & 4.66 & 0.004 & 22.43 & 268 \\
Aid repayments & 0.464 & 0.690 & -0.445 & 4.91 & 268 \\
Initial GDP per capita (log) & 7.06 & 1.10 & 4.53 & 9.75 & 268 \\
Institutional quality & 4.53 & 1.58 & 0 & 8.33 & 268 \\
Inflation & 0.244 & 0.429 & 0.0003 & 3.84 & 268 \\
Trade policy (Sachs-Warner) & 0.453 & 0.482 & 0 & 1 & 268 \\
M2/GDP & 33.68 & 20.99 & 4.10 & 132.65 & 268 \\
Budget balance & -3.57 & 3.75 & -26.12 & 3.14 & 268 \\
Tropical & 0.537 & 0.499 & 0 & 1 & 268 \\
Civil war & 0.152 & 0.360 & 0 & 1 & 268 \\
East Asia & 0.075 & 0.265 & 0 & 1 & 316 \\
Sub-Saharan Africa & 0.306 & 0.461 & 0 & 1 & 316 \\
Fertility rate & 4.29 & 1.86 & 1.16 & 8.49 & 316 \\
Infant mortality rate & 64.02 & 42.24 & 4.35 & 199 & 316 \\
Initial school & 46.87 & 27.91 & 1.92 & 109.23 & 316 \\
Urban & 45.68 & 21.70 & 3.53 & 91.97 & 316 \\
\hline
\end{tabular}

Notes: All variables are based on 4-year averages of the data. The variables humanitarian aid, non-humanitarian aid, aid repayments, M2, and budget balance are expressed as fractions of GDP. Initial GDP enters in log form, while trade policy, tropical, civil war, East Asia, and Sub-Saharan Africa enter as 0/1 dummies. A detailed description of the variables and their sources appears in Table B2. 
Table 2

Benchmark findings

\begin{tabular}{|c|c|c|c|c|c|c|c|c|c|c|}
\hline & \multicolumn{2}{|c|}{$\begin{array}{c}(1) \\
\text { FE(t) }\end{array}$} & \multicolumn{2}{|c|}{$\begin{array}{c}(2) \\
\text { FE }(i, t)\end{array}$} & \multicolumn{2}{|c|}{$\begin{array}{c}\text { (3) } \\
\text { GMM-DIFF }\end{array}$} & \multicolumn{2}{|c|}{$\begin{array}{c}\text { (4) } \\
\text { GMM-SYS } \\
\end{array}$} & \multicolumn{2}{|c|}{$\begin{array}{c}(5) \\
\text { 3SLS(t) }\end{array}$} \\
\hline & fertility & growth & fertility & growth & fertility & growth & fertility & growth & fertility & growth \\
\hline Initial GDP per capita $(\log )$ & $\begin{array}{c}0.002 \\
(0.980)\end{array}$ & $\begin{array}{c}-0.193 \\
(0.404)\end{array}$ & $\begin{array}{c}0.143 \\
(0.257)\end{array}$ & $\begin{array}{c}-2.24 \\
(0.018)\end{array}$ & $\begin{array}{c}\mathbf{- 0 . 0 9 7} \\
(0.725)\end{array}$ & $\begin{array}{c}-4.26 \\
(0.210)\end{array}$ & $\begin{array}{c}-0.361 \\
(0.091)\end{array}$ & $\begin{array}{c}-1.89 \\
(0.067)\end{array}$ & $\begin{array}{c}0.183 \\
(0.145)\end{array}$ & $\begin{array}{l}-0.756 \\
(0.014)\end{array}$ \\
\hline Infant mortality rate & $\begin{array}{c}0.017 \\
(0.000)\end{array}$ & & $\begin{array}{c}0.014 \\
(0.000)\end{array}$ & & $\begin{array}{c}0.009 \\
(0.041)\end{array}$ & & $\begin{array}{c}0.022 \\
(0.000)\end{array}$ & & $\begin{array}{c}0.017 \\
(0.000)\end{array}$ & \\
\hline Initial school & $\begin{array}{l}-0.023 \\
(0.000)\end{array}$ & & $\begin{array}{l}-0.002 \\
(0.524)\end{array}$ & & $\begin{array}{l}-0.007 \\
(0.193)\end{array}$ & & $\begin{array}{l}-0.015 \\
(0.012)\end{array}$ & & $\begin{array}{l}-0.024 \\
(0.000)\end{array}$ & \\
\hline Urban & $\begin{array}{l}-0.002 \\
(0.587)\end{array}$ & & $\begin{array}{l}-0.012 \\
(0.137)\end{array}$ & & $\begin{array}{c}-0.082 \\
(0.003)\end{array}$ & & $\begin{array}{c}0.011 \\
(0.478)\end{array}$ & & $\begin{array}{c}-0.008 \\
(0.140)\end{array}$ & \\
\hline Fertility rate & & & & & & & & & & $\begin{array}{l}-0.652 \\
(0.081)\end{array}$ \\
\hline Institutional quality & & $\begin{array}{c}0.297 \\
(0.017)\end{array}$ & & $\begin{array}{l}-0.106 \\
(0.620)\end{array}$ & & $\begin{array}{l}-0.009 \\
(0.978)\end{array}$ & & $\begin{array}{c}0.191 \\
(0.597)\end{array}$ & & $\begin{array}{c}0.231 \\
(0.186)\end{array}$ \\
\hline Inflation & & $\begin{array}{c}-2.59 \\
(0.000)\end{array}$ & & $\begin{array}{c}-2.60 \\
(0.000)\end{array}$ & & $\begin{array}{c}-1.12 \\
(0.214)\end{array}$ & & $\begin{array}{c}-1.89 \\
(0.053)\end{array}$ & & $\begin{array}{c}-3.14 \\
(0.000)\end{array}$ \\
\hline Trade policy (Sachs-Warner) & & $\begin{array}{c}1.04 \\
(0.036)\end{array}$ & & $\begin{array}{c}0.416 \\
(0.537)\end{array}$ & & $\begin{array}{c}0.902 \\
(0.300)\end{array}$ & & $\begin{array}{c}1.44 \\
(0.047)\end{array}$ & & $\begin{array}{c}0.124 \\
(0.845)\end{array}$ \\
\hline M2/GDP & & $\begin{array}{l}-0.011 \\
(0.285)\end{array}$ & & $\begin{array}{l}-0.037 \\
(0.073)\end{array}$ & & $\begin{array}{l}-0.031 \\
(0.630)\end{array}$ & & $\begin{array}{l}-0.047 \\
(0.084)\end{array}$ & & $\begin{array}{l}-0.008 \\
(0.533)\end{array}$ \\
\hline Budget balance & & $\begin{array}{c}0.032 \\
(0.506)\end{array}$ & & $\begin{array}{c}0.151 \\
(0.015)\end{array}$ & & $\begin{array}{c}0.463 \\
(0.012)\end{array}$ & & $\begin{array}{c}0.377 \\
(\mathbf{0 . 0 0 6})\end{array}$ & & $\begin{array}{l}-0.009 \\
(0.860)\end{array}$ \\
\hline Tropical & & $\begin{array}{l}-0.651 \\
(0.073)\end{array}$ & & & & & & $\begin{array}{l}-0.596 \\
(0.798)\end{array}$ & & $\begin{array}{l}-0.550 \\
(0.243)\end{array}$ \\
\hline Civil war & & $\begin{array}{l}-0.280 \\
(0.572)\end{array}$ & & $\begin{array}{l}-0.225 \\
(0.702)\end{array}$ & & $\begin{array}{l}-0.421 \\
(0.655)\end{array}$ & & $\begin{array}{l}-0.731 \\
(0.546)\end{array}$ & & $\begin{array}{l}-0.128 \\
(0.821)\end{array}$ \\
\hline East Asia & $\begin{array}{l}-0.235 \\
(0.178)\end{array}$ & $\begin{array}{c}1.94 \\
(0.003)\end{array}$ & & & & & $\begin{array}{c}-1.89 \\
(0.301)\end{array}$ & $\begin{array}{c}5.48 \\
(0.210)\end{array}$ & $\begin{array}{c}-0.444 \\
(0.035)\end{array}$ & $\begin{array}{c}0.617 \\
(0.490)\end{array}$ \\
\hline Sub-Saharan Africa & $\begin{array}{c}0.615 \\
(0.000)\end{array}$ & $\begin{array}{c}-2.75 \\
(0.000)\end{array}$ & & & & & $\begin{array}{l}-0.663 \\
(0.541)\end{array}$ & $\begin{array}{c}-4.99 \\
(0.157)\end{array}$ & $\begin{array}{c}0.797 \\
(0.000)\end{array}$ & $\begin{array}{c}-1.24 \\
(0.148)\end{array}$ \\
\hline Aid repayments & $\begin{array}{c}0.022 \\
(0.446)\end{array}$ & $\begin{array}{c}0.039 \\
(0.887)\end{array}$ & $\begin{array}{c}0.022 \\
(0.277)\end{array}$ & $\begin{array}{l}-0.318 \\
(0.355)\end{array}$ & $\begin{array}{c}-0.005 \\
(0.694)\end{array}$ & $\begin{array}{l}-\mathbf{0 . 6 3 3} \\
(\mathbf{0 . 1 7 2})\end{array}$ & $\begin{array}{c}0.005 \\
(0.757)\end{array}$ & $\begin{array}{c}-1.02 \\
(0.099)\end{array}$ & $\begin{array}{c}0.081 \\
(0.446)\end{array}$ & $\begin{array}{c}0.123 \\
(0.724)\end{array}$ \\
\hline Humanitarian aid & $\begin{array}{c}0.004 \\
(0.769)\end{array}$ & $\begin{array}{c}0.377 \\
(0.081)\end{array}$ & $\begin{array}{c}0.014 \\
(0.174)\end{array}$ & $\begin{array}{l}-0.070 \\
(0.811)\end{array}$ & $\begin{array}{l}-0.010 \\
(0.055)\end{array}$ & $\begin{array}{l}-0.371 \\
(0.521)\end{array}$ & $\begin{array}{l}-0.016 \\
(0.052)\end{array}$ & $\begin{array}{l}-0.267 \\
(0.664)\end{array}$ & $\begin{array}{c}0.074 \\
(0.406)\end{array}$ & $\begin{array}{c}0.134 \\
(0.659)\end{array}$ \\
\hline $\begin{array}{l}\text { Countries / Observations } \\
\mathrm{R}^{2}\end{array}$ & $\begin{array}{c}66 / 316 \\
0.779\end{array}$ & $\begin{array}{c}50 / 268 \\
0.401\end{array}$ & $\begin{array}{c}66 / 316 \\
0.805\end{array}$ & $\begin{array}{c}50 / 268 \\
0.295\end{array}$ & $62 / 190$ & $47 / 210$ & $66 / 316$ & $50 / 268$ & $\begin{array}{c}48 / 166 \\
0.844\end{array}$ & $\begin{array}{c}48 / 166 \\
0.331\end{array}$ \\
\hline $\begin{array}{l}\text { Number of Instruments } \\
\text { Hansen J-statistic ( } p \text {-value) } \\
\text { AR(2) test ( } p \text {-value) }\end{array}$ & & & & & $\begin{array}{c}42 \\
0.294 \\
0.243\end{array}$ & $\begin{array}{c}54 \\
0.854 \\
0.488\end{array}$ & $\begin{array}{c}49 \\
0.277 \\
0.131\end{array}$ & $\begin{array}{c}64 \\
0.956 \\
0.532\end{array}$ & & \\
\hline
\end{tabular}

Notes: p-values in parentheses based on robust and clustered by country standard errors. Constant term, country and time dummies not reported. Instrumented variables are in bold type. Instruments

in regressions (3) and (4): unrestricted lags of instrumented variables starting with the second lag. 
Table 3

Testing the proxy of humanitarian aid: alternative definitions

\begin{tabular}{|c|c|c|c|c|c|c|c|c|c|c|c|c|}
\hline & \multicolumn{2}{|c|}{ (1) } & \multicolumn{2}{|c|}{ (2) } & \multicolumn{2}{|c|}{ (3) } & \multicolumn{2}{|c|}{ (4) } & \multicolumn{2}{|c|}{ (5) } & \multicolumn{2}{|c|}{$(6)$} \\
\hline & $\begin{array}{r}\text { Or } \\
\text { humani } \\
\text { augme } \\
\text { hea }\end{array}$ & $\begin{array}{l}\text { nal } \\
\text { rian aid } \\
\text { ed with } \\
\text { aid }\end{array}$ & $\begin{array}{l}\text { Original } \\
\text { aid augn } \\
\text { health an }\end{array}$ & $\begin{array}{l}\text { nanitarian } \\
\text { hted with } \\
\text { griculture } \\
\end{array}$ & $\begin{array}{r}\text { Original } \\
\text { aid anc } \\
\text { sep }\end{array}$ & $\begin{array}{l}\text { anitarian } \\
\text { lith aid } \\
\text { ely }\end{array}$ & $\begin{array}{r}\text { Original h } \\
\text { aid, hea } \\
\text { agricu } \\
\text { sepa }\end{array}$ & $\begin{array}{l}\text { manitarian } \\
\text { aid and } \\
\text { are aid } \\
\text { tely }\end{array}$ & $\begin{array}{r}\text { Reconstr } \\
\text { exclu } \\
\text { original }\end{array}$ & $\begin{array}{l}\text { on relief } \\
\text { from } \\
\text { anitarian }\end{array}$ & $\begin{array}{r}\text { Humanit } \\
\text { column } \\
\text { and agr } \\
\text { sep }\end{array}$ & $\begin{array}{l}\text { aid from } \\
\text { ealth aid } \\
\text { ture aid } \\
\text { ely }\end{array}$ \\
\hline & fertility & growth & fertility & growth & fertility & growth & fertility & growth & fertility & growth & fertility & growth \\
\hline Initial GDP per capita (log) & $\begin{array}{c}0.284 \\
(0.038)\end{array}$ & $\begin{array}{c}-2.46 \\
(0.017)\end{array}$ & $\begin{array}{c}0.309 \\
(0.020)\end{array}$ & $\begin{array}{c}-2.04 \\
(0.037)\end{array}$ & $\begin{array}{c}0.002 \\
(0.985)\end{array}$ & $\begin{array}{c}-2.57 \\
(0.039)\end{array}$ & $\begin{array}{l}-0.032 \\
(0.786)\end{array}$ & $\begin{array}{c}-2.28 \\
(0.059)\end{array}$ & $\begin{array}{c}0.239 \\
(0.071)\end{array}$ & $\begin{array}{c}-2.26 \\
(0.020)\end{array}$ & $\begin{array}{c}-0.030 \\
(0.798)\end{array}$ & $\begin{array}{c}-2.22 \\
(0.064)\end{array}$ \\
\hline Infant mortality rate & $\begin{array}{c}0.014 \\
(0.000)\end{array}$ & & $\begin{array}{c}0.013 \\
(0.000)\end{array}$ & & $\begin{array}{c}0.011 \\
(0.000)\end{array}$ & & $\begin{array}{c}0.010 \\
(0.000)\end{array}$ & & $\begin{array}{c}0.014 \\
(0.000)\end{array}$ & & $\begin{array}{c}0.010 \\
(0.000)\end{array}$ & \\
\hline Initial school & $\begin{array}{c}-0.001 \\
(0.690)\end{array}$ & & $\begin{array}{l}-0.003 \\
(0.281)\end{array}$ & & $\begin{array}{c}-0.001 \\
(0.976)\end{array}$ & & $\begin{array}{l}-0.002 \\
(0.520)\end{array}$ & & $\begin{array}{l}-0.001 \\
(0.668)\end{array}$ & & $\begin{array}{l}-0.002 \\
(0.497)\end{array}$ & \\
\hline Urban & $\begin{array}{c}-0.014 \\
(0.073)\end{array}$ & & $\begin{array}{l}-0.018 \\
(0.026)\end{array}$ & & $\begin{array}{c}-0.008 \\
(0.284)\end{array}$ & & $\begin{array}{l}-0.007 \\
(0.347)\end{array}$ & & $\begin{array}{l}-0.014 \\
(0.082)\end{array}$ & & $\begin{array}{c}-0.007 \\
(0.343)\end{array}$ & \\
\hline Institutional quality & & $\begin{array}{c}-0.151 \\
(0.454)\end{array}$ & & $\begin{array}{c}-0.084 \\
(0.708)\end{array}$ & & $\begin{array}{l}-0.220 \\
(0.412)\end{array}$ & & $\begin{array}{c}-0.370 \\
(0.175)\end{array}$ & & $\begin{array}{l}-0.130 \\
(0.553)\end{array}$ & & $\begin{array}{l}-0.361 \\
(0.185)\end{array}$ \\
\hline Inflation & & $\begin{array}{c}-2.59 \\
(0.000)\end{array}$ & & $\begin{array}{c}-2.66 \\
(0.000)\end{array}$ & & $\begin{array}{c}-2.48 \\
(0.000)\end{array}$ & & $\begin{array}{c}-2.18 \\
(0.000)\end{array}$ & & $\begin{array}{c}-2.59 \\
(0.000)\end{array}$ & & $\begin{array}{c}-2.18 \\
(0.000)\end{array}$ \\
\hline Trade policy & & $\begin{array}{c}0.339 \\
(0.625)\end{array}$ & & $\begin{array}{c}0.281 \\
(0.688)\end{array}$ & & $\begin{array}{c}0.525 \\
(0.497)\end{array}$ & & $\begin{array}{c}0.633 \\
(0.390)\end{array}$ & & $\begin{array}{c}0.410 \\
(0.547)\end{array}$ & & $\begin{array}{c}0.658 \\
(0.370)\end{array}$ \\
\hline M2/GDP & & $\begin{array}{c}-0.038 \\
(0.064)\end{array}$ & & $\begin{array}{l}-0.034 \\
(0.077)\end{array}$ & & $\begin{array}{l}-0.027 \\
(0.323)\end{array}$ & & $\begin{array}{l}-0.024 \\
(0.373)\end{array}$ & & $\begin{array}{c}-0.038 \\
(0.064)\end{array}$ & & $\begin{array}{l}-0.024 \\
(0.372)\end{array}$ \\
\hline Budget balance & & $\begin{array}{c}0.153 \\
(0.015)\end{array}$ & & $\begin{array}{c}0.151 \\
(0.017)\end{array}$ & & $\begin{array}{c}0.150 \\
(0.025)\end{array}$ & & $\begin{array}{c}0.167 \\
(0.010)\end{array}$ & & $\begin{array}{c}0.156 \\
(0.013)\end{array}$ & & $\begin{array}{c}0.169 \\
(0.009)\end{array}$ \\
\hline Civil war & & $\begin{array}{c}-0.234 \\
(0.691)\end{array}$ & & $\begin{array}{l}-0.153 \\
(0.794)\end{array}$ & & $\begin{array}{l}-0.136 \\
(0.835)\end{array}$ & & $\begin{array}{c}-0.386 \\
(0.537)\end{array}$ & & $\begin{array}{l}-0.235 \\
(0.691)\end{array}$ & & $\begin{array}{c}-0.393 \\
(0.529)\end{array}$ \\
\hline Aid repayments & $\begin{array}{c}0.010 \\
(0.633)\end{array}$ & $\begin{array}{c}-0.321 \\
(0.353)\end{array}$ & $\begin{array}{c}-0.013 \\
(0.616)\end{array}$ & $\begin{array}{c}-0.414 \\
(0.245)\end{array}$ & $\begin{array}{c}-0.013 \\
(0.540)\end{array}$ & $\begin{array}{l}-0.339 \\
(0.343)\end{array}$ & $\begin{array}{c}-0.020 \\
(0.361)\end{array}$ & $\begin{array}{c}-0.551 \\
(0.126)\end{array}$ & $\begin{array}{c}0.015 \\
(0.446)\end{array}$ & $\begin{array}{l}-0.310 \\
(0.369)\end{array}$ & $\begin{array}{l}-0.020 \\
(0.354)\end{array}$ & $\begin{array}{c}-0.548 \\
(0.128)\end{array}$ \\
\hline Humanitarian aid & $\begin{array}{c}0.042 \\
(0.301)\end{array}$ & $\begin{array}{c}-0.184 \\
(0.581)\end{array}$ & $\begin{array}{c}0.033 \\
(0.333)\end{array}$ & $\begin{array}{c}0.071 \\
(0.784)\end{array}$ & $\begin{array}{c}0.008 \\
(0.370)\end{array}$ & $\begin{array}{l}-0.245 \\
(0.573)\end{array}$ & $\begin{array}{c}0.009 \\
(0.323)\end{array}$ & $\begin{array}{l}-0.101 \\
(0.808)\end{array}$ & $\begin{array}{c}0.029 \\
(0.574)\end{array}$ & $\begin{array}{c}-0.062 \\
(0.863)\end{array}$ & $\begin{array}{c}0.011 \\
(0.303)\end{array}$ & $\begin{array}{c}-0.028 \\
(0.946)\end{array}$ \\
\hline Health aid & & & & & $\begin{array}{c}0.121 \\
(0.141)\end{array}$ & $\begin{array}{l}-0.450 \\
(0.562)\end{array}$ & $\begin{array}{c}0.075 \\
(0.229)\end{array}$ & $\begin{array}{l}-0.281 \\
(0.703)\end{array}$ & & & $\begin{array}{c}0.074 \\
(0.235)\end{array}$ & $\begin{array}{c}-0.276 \\
(0.707)\end{array}$ \\
\hline Agriculture aid & & & & & & & $\begin{array}{c}0.069 \\
(0.123)\end{array}$ & $\begin{array}{c}0.429 \\
(0.310)\end{array}$ & & & $\begin{array}{c}0.070 \\
(0.120)\end{array}$ & $\begin{array}{c}0.442 \\
(0.294)\end{array}$ \\
\hline $\begin{array}{l}\text { Countries / Observations } \\
\mathrm{R}^{2}\end{array}$ & $\begin{array}{c}66 / 313 \\
0.817\end{array}$ & $\begin{array}{c}50 / 266 \\
0.302\end{array}$ & $\begin{array}{c}66 / 307 \\
0.823\end{array}$ & $\begin{array}{c}50 / 261 \\
0.286\end{array}$ & $\begin{array}{c}66 / 291 \\
0.831\end{array}$ & $\begin{array}{c}50 / 232 \\
0.280\end{array}$ & $\begin{array}{c}60 / 268 \\
0.842\end{array}$ & $\begin{array}{c}44 / 217 \\
0.300\end{array}$ & $\begin{array}{c}66 / 311 \\
0.817\end{array}$ & $\begin{array}{c}50 / 266 \\
0.301\end{array}$ & $\begin{array}{c}60 / 269 \\
0.842\end{array}$ & $\begin{array}{c}44 / 217 \\
0.300\end{array}$ \\
\hline
\end{tabular}

humanitarian aid is qualitatively the same when we use the rest of the techniques: FE(t), GMM-DIFF, GMM-SYS, and 3SLS(t). 
Table 4

Testing the measure of fertility: alternative variables

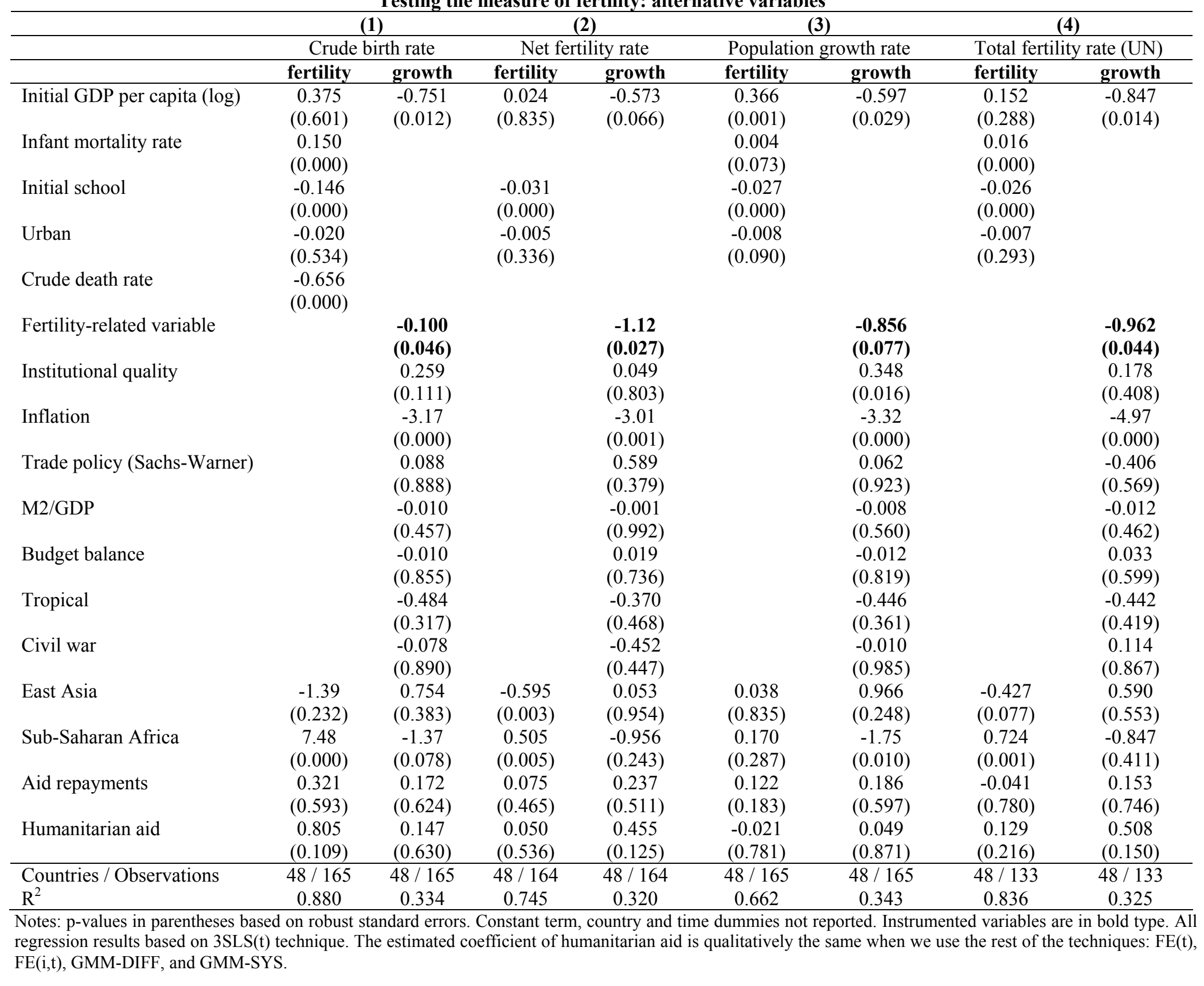


Table 5

Controlling for endogeneity: varying instrument lag structure

GMM-DIFF GMM-SYS

\begin{tabular}{|c|c|c|c|c|c|c|c|c|c|c|c|c|}
\hline & \multicolumn{6}{|c|}{ GMM-DIFF } & \multicolumn{6}{|c|}{ GMM-SYS } \\
\hline & \multicolumn{2}{|c|}{ (1) } & \multicolumn{2}{|c|}{ (2) } & \multicolumn{2}{|c|}{ (3) } & \multicolumn{2}{|c|}{ (1) } & \multicolumn{2}{|c|}{ (2) } & \multicolumn{2}{|c|}{ (3) } \\
\hline & fertility & growth & fertility & growth & fertility & growth & fertility & growth & fertility & growth & fertility & growth \\
\hline Initial GDP per capita (log) & $\begin{array}{l}-0.268 \\
(0.372)\end{array}$ & $\begin{array}{c}-4.01 \\
(0.090)\end{array}$ & $\begin{array}{l}-0.363 \\
(0.223)\end{array}$ & $\begin{array}{c}-4.29 \\
(0.004)\end{array}$ & $\begin{array}{l}-0.358 \\
(0.160)\end{array}$ & $\begin{array}{c}-4.83 \\
(0.093)\end{array}$ & $\begin{array}{c}0.252 \\
(0.123)\end{array}$ & $\begin{array}{l}-0.437 \\
(0.675)\end{array}$ & $\begin{array}{c}0.270 \\
(0.115)\end{array}$ & $\begin{array}{c}-1.09 \\
(0.036)\end{array}$ & $\begin{array}{c}0.228 \\
(0.211)\end{array}$ & $\begin{array}{l}-0.826 \\
(0.329)\end{array}$ \\
\hline Infant mortality rate & $\begin{array}{c}0.007 \\
(0.168)\end{array}$ & & $\begin{array}{c}0.009 \\
(0.059)\end{array}$ & & $\begin{array}{c}0.009 \\
(0.141)\end{array}$ & & $\begin{array}{c}0.035 \\
(0.000)\end{array}$ & & $\begin{array}{c}0.036 \\
(0.000)\end{array}$ & & $\begin{array}{c}0.036 \\
(0.000)\end{array}$ & \\
\hline Initial school & $\begin{array}{l}-0.010 \\
(0.002)\end{array}$ & & $\begin{array}{l}-0.009 \\
(0.055)\end{array}$ & & $\begin{array}{l}-0.007 \\
(0.133)\end{array}$ & & $\begin{array}{l}-0.023 \\
(0.002)\end{array}$ & & $\begin{array}{l}-0.021 \\
(0.004)\end{array}$ & & $\begin{array}{l}-0.022 \\
(0.005)\end{array}$ & \\
\hline Urban & $\begin{array}{l}-0.065 \\
(0.004)\end{array}$ & & $\begin{array}{l}-0.055 \\
(0.008)\end{array}$ & & $\begin{array}{l}-0.067 \\
(0.008)\end{array}$ & & $\begin{array}{c}0.004 \\
(0.516)\end{array}$ & & $\begin{array}{c}0.005 \\
(0.516)\end{array}$ & & $\begin{array}{c}0.006 \\
(0.438)\end{array}$ & \\
\hline Institutional quality & & $\begin{array}{l}-0.154 \\
(0.632)\end{array}$ & & $\begin{array}{l}-0.368 \\
(0.221)\end{array}$ & & $\begin{array}{l}-0.227 \\
(0.555)\end{array}$ & & $\begin{array}{c}0.538 \\
(0.067)\end{array}$ & & $\begin{array}{c}0.406 \\
(0.042)\end{array}$ & & $\begin{array}{c}0.111 \\
(\mathbf{0 . 6 5 9})\end{array}$ \\
\hline Inflation & & $\begin{array}{c}-1.30 \\
(0.199)\end{array}$ & & $\begin{array}{l}-2.21 \\
(0.097)\end{array}$ & & $\begin{array}{c}-1.21 \\
(0.310)\end{array}$ & & $\begin{array}{c}-2.09 \\
(0.046)\end{array}$ & & $\begin{array}{c}-2.39 \\
(0.003)\end{array}$ & & $\begin{array}{c}-2.74 \\
(0.019)\end{array}$ \\
\hline $\begin{array}{l}\text { Trade policy (Sachs- } \\
\text { Warner) }\end{array}$ & & $\begin{array}{c}0.663 \\
(0.508)\end{array}$ & & $\begin{array}{c}1.53 \\
(0.050)\end{array}$ & & $\begin{array}{c}1.33 \\
(0.357)\end{array}$ & & $\begin{array}{c}0.601 \\
(0.463)\end{array}$ & & $\begin{array}{c}1.11 \\
(0.024)\end{array}$ & & $\begin{array}{c}0.937 \\
(0.138)\end{array}$ \\
\hline M2/GDP & & $\begin{array}{l}-0.026 \\
(0.285)\end{array}$ & & $\begin{array}{l}-0.028 \\
(0.314)\end{array}$ & & $\begin{array}{l}-0.011 \\
(0.825)\end{array}$ & & $\begin{array}{l}-0.036 \\
(0.006)\end{array}$ & & $\begin{array}{l}-0.045 \\
(0.004)\end{array}$ & & $\begin{array}{l}-0.040 \\
(0.014)\end{array}$ \\
\hline Budget balance & & $\begin{array}{c}0.376 \\
(0.008)\end{array}$ & & $\begin{array}{c}0.328 \\
(0.039)\end{array}$ & & $\begin{array}{c}0.359 \\
(0.118)\end{array}$ & & $\begin{array}{c}0.091 \\
(0.383)\end{array}$ & & $\begin{array}{c}0.048 \\
(0.610)\end{array}$ & & $\begin{array}{c}0.066 \\
(0.395)\end{array}$ \\
\hline Tropical & & & & & & & & $\begin{array}{l}-0.867 \\
(0.343)\end{array}$ & & $\begin{array}{c}-2.16 \\
(0.027)\end{array}$ & & $\begin{array}{c}-2.28 \\
(0.034)\end{array}$ \\
\hline Civil war & & $\begin{array}{l}-0.036 \\
(0.979)\end{array}$ & & $\begin{array}{l}-0.343 \\
(0.696)\end{array}$ & & $\begin{array}{c}0.168 \\
(0.880)\end{array}$ & & $\begin{array}{l}-0.390 \\
(0.713)\end{array}$ & & $\begin{array}{l}-0.370 \\
(0.631)\end{array}$ & & $\begin{array}{l}-0.503 \\
(0.523)\end{array}$ \\
\hline East Asia & & & & & & & $\begin{array}{c}0.076 \\
(0.878)\end{array}$ & $\begin{array}{c}3.37 \\
(0.037)\end{array}$ & $\begin{array}{c}0.021 \\
(0.976)\end{array}$ & $\begin{array}{c}4.85 \\
(0.034)\end{array}$ & $\begin{array}{c}0.179 \\
(0.686)\end{array}$ & $\begin{array}{c}4.90 \\
(0.028)\end{array}$ \\
\hline Sub-Saharan Africa & & & & & & & $\begin{array}{l}-0.071 \\
(0.837)\end{array}$ & $\begin{array}{l}-3.77 \\
(0.200)\end{array}$ & $\begin{array}{c}0.033 \\
(0.922)\end{array}$ & $\begin{array}{l}-3.40 \\
(0.014)\end{array}$ & $\begin{array}{l}-0.115 \\
(0.773)\end{array}$ & $\begin{array}{c}-3.57 \\
(0.023)\end{array}$ \\
\hline Aid repayments & $\begin{array}{l}-\mathbf{0 . 0 0 7} \\
(\mathbf{0 . 4 5 8 )}\end{array}$ & $\begin{array}{l}-0.540 \\
(0.048)\end{array}$ & $\begin{array}{l}-0.010 \\
(0.340)\end{array}$ & $\begin{array}{l}-0.599 \\
(0.077)\end{array}$ & $\begin{array}{l}-0.008 \\
(0.411)\end{array}$ & $\begin{array}{l}-0.627 \\
(0.044)\end{array}$ & $\begin{array}{c}0.032 \\
(0.206)\end{array}$ & $\begin{array}{l}-0.120 \\
(0.651)\end{array}$ & $\begin{array}{c}0.034 \\
(0.360)\end{array}$ & $\begin{array}{l}-0.178 \\
(0.544)\end{array}$ & $\begin{array}{c}0.037 \\
(\mathbf{0 . 3 8 6})\end{array}$ & $\begin{array}{l}-0.268 \\
(0.209)\end{array}$ \\
\hline Humanitarian aid & $\begin{array}{l}-0.013 \\
(0.064)\end{array}$ & $\begin{array}{l}-0.604 \\
(0.230)\end{array}$ & $\begin{array}{l}-0.014 \\
(0.025)\end{array}$ & $\begin{array}{l}-0.705 \\
(0.218)\end{array}$ & $\begin{array}{l}-0.014 \\
(0.012)\end{array}$ & $\begin{array}{l}-0.053 \\
(0.941)\end{array}$ & $\begin{array}{l}-0.009 \\
(0.336)\end{array}$ & $\begin{array}{c}0.409 \\
(0.512)\end{array}$ & $\begin{array}{l}-0.011 \\
(0.273)\end{array}$ & $\begin{array}{l}-0.080 \\
(0.889)\end{array}$ & $\begin{array}{l}-0.012 \\
(0.297)\end{array}$ & $\begin{array}{c}0.409 \\
(0.448)\end{array}$ \\
\hline Countries / Observations & $62 / 190$ & $47 / 210$ & $62 / 190$ & $47 / 210$ & $62 / 190$ & $47 / 210$ & $66 / 316$ & $50 / 268$ & $66 / 316$ & $50 / 268$ & $66 / 316$ & $50 / 268$ \\
\hline Number of Instruments & 98 & 148 & 56 & 133 & 45 & 98 & 132 & 202 & 90 & 187 & 79 & 152 \\
\hline Hansen J-statistic ( $p$-value) & 0.996 & 1.000 & 0.365 & 1.000 & 0.217 & 1.000 & 1.000 & 1.000 & 0.980 & 1.000 & 0.785 & 1.000 \\
\hline $\operatorname{AR}(2)$ test ( $p$-value) & 0.186 & 0.189 & 0.175 & 0.311 & 0.188 & 0.379 & 0.190 & 0.077 & 0.180 & 0.051 & 0.175 & 0.078 \\
\hline $\begin{array}{l}\text { No. of lags of endogenous } \\
\text { variables as instruments }\end{array}$ & $\begin{array}{l}\text { Two to } \\
\text { all }\end{array}$ & $\begin{array}{l}\text { Two to } \\
\text { all }\end{array}$ & $\begin{array}{l}\text { Two to } \\
\text { four }\end{array}$ & $\begin{array}{l}\text { Two to } \\
\text { four }\end{array}$ & $\begin{array}{c}\text { Two to } \\
\text { three }\end{array}$ & $\begin{array}{l}\text { Two to } \\
\text { three }\end{array}$ & $\begin{array}{c}\text { Two to } \\
\text { all }\end{array}$ & $\begin{array}{c}\text { Two to } \\
\text { all }\end{array}$ & $\begin{array}{l}\text { Two to } \\
\text { four }\end{array}$ & $\begin{array}{l}\text { Two to } \\
\text { four }\end{array}$ & $\begin{array}{c}\text { Two to } \\
\text { three }\end{array}$ & $\begin{array}{c}\text { Two to } \\
\text { three }\end{array}$ \\
\hline
\end{tabular}

the estimated coefficient of humanitarian aid is qualitatively the same even when we use the "collapse" command to limit the number of instruments to be less than the number of countries. 
Table 6

Testing the specification: alternative $\&$ additional control variables

\begin{tabular}{|c|c|c|c|c|c|c|c|c|c|c|c|c|}
\hline & \multicolumn{2}{|c|}{ (1) } & \multicolumn{2}{|c|}{ (2) } & \multicolumn{2}{|c|}{ (3) } & \multicolumn{2}{|c|}{ (4) } & \multicolumn{2}{|c|}{ (5) } & \multicolumn{2}{|c|}{ (6) } \\
\hline & fertility & growth & fertility & growth & fertility & growth & fertility & growth & fertility & growth & fertility & growth \\
\hline Initial GDP per capita (log) & $\begin{array}{c}0.246 \\
(0.017)\end{array}$ & $\begin{array}{l}-0.799 \\
(0.002)\end{array}$ & $\begin{array}{c}0.265 \\
(0.043)\end{array}$ & $\begin{array}{c}-0.573 \\
(0.071)\end{array}$ & $\begin{array}{c}0.113 \\
(0.460)\end{array}$ & $\begin{array}{c}-0.619 \\
(0.070)\end{array}$ & $\begin{array}{c}0.217 \\
(0.084)\end{array}$ & $\begin{array}{c}-0.707 \\
(0.020)\end{array}$ & $\begin{array}{c}0.184 \\
(0.143)\end{array}$ & $\begin{array}{c}-0.761 \\
(0.015)\end{array}$ & $\begin{array}{c}0.185 \\
(0.137)\end{array}$ & $\begin{array}{c}-0.683 \\
(0.024)\end{array}$ \\
\hline Infant mortality rate & $\begin{array}{c}0.021 \\
(0.000)\end{array}$ & & & & $\begin{array}{c}0.015 \\
(0.000)\end{array}$ & & $\begin{array}{c}0.017 \\
(0.000)\end{array}$ & & $\begin{array}{c}0.017 \\
(0.000)\end{array}$ & & $\begin{array}{c}0.018 \\
(0.000)\end{array}$ & \\
\hline Initial school & $\begin{array}{l}-0.023 \\
(0.000)\end{array}$ & & $\begin{array}{l}-0.026 \\
(0.000)\end{array}$ & & $\begin{array}{l}-0.025 \\
(0.000)\end{array}$ & & $\begin{array}{l}-0.024 \\
(0.000)\end{array}$ & & $\begin{array}{l}-0.024 \\
(0.000)\end{array}$ & $\begin{array}{c}0.003 \\
(0.918)\end{array}$ & $\begin{array}{l}-0.024 \\
(0.000)\end{array}$ & \\
\hline Urban & $\begin{array}{l}-0.008 \\
(0.051)\end{array}$ & & $\begin{array}{l}-0.010 \\
(0.047)\end{array}$ & & $\begin{array}{c}-0.008 \\
(0.253)\end{array}$ & & $\begin{array}{l}-0.008 \\
(0.133)\end{array}$ & & $\begin{array}{c}-0.008 \\
(0.137)\end{array}$ & & $\begin{array}{l}-0.007 \\
(0.183)\end{array}$ & \\
\hline Fertility rate & & $\begin{array}{c}-0.536 \\
(0.095)\end{array}$ & & $\begin{array}{c}-0.499 \\
(0.320)\end{array}$ & & $\begin{array}{c}-0.829 \\
(0.052)\end{array}$ & & $\begin{array}{c}-0.689 \\
(0.070)\end{array}$ & & $\begin{array}{c}-0.585 \\
(0.458)\end{array}$ & & $\begin{array}{c}-0.594 \\
(0.103)\end{array}$ \\
\hline Institutional quality & & $\begin{array}{c}0.370 \\
(0.016)\end{array}$ & & $\begin{array}{c}0.262 \\
(0.122)\end{array}$ & & $\begin{array}{c}0.153 \\
(0.409)\end{array}$ & & $\begin{array}{c}0.229 \\
(0.188)\end{array}$ & & $\begin{array}{c}0.242 \\
(0.330)\end{array}$ & & $\begin{array}{c}0.243 \\
(0.159)\end{array}$ \\
\hline Inflation & & $\begin{array}{c}-3.37 \\
(0.000)\end{array}$ & & $\begin{array}{c}-2.57 \\
(0.000)\end{array}$ & & $\begin{array}{c}-3.48 \\
(0.001)\end{array}$ & & $\begin{array}{c}-3.21 \\
(0.000)\end{array}$ & & $\begin{array}{c}-3.13 \\
(0.000)\end{array}$ & & $\begin{array}{c}-2.92 \\
(0.001)\end{array}$ \\
\hline Trade policy & & $\begin{array}{c}0.011 \\
(0.038)\end{array}$ & & $\begin{array}{c}0.831 \\
(0.157)\end{array}$ & & $\begin{array}{c}0.179 \\
(0.823)\end{array}$ & & $\begin{array}{c}0.051 \\
(0.936)\end{array}$ & & $\begin{array}{c}0.133 \\
(0.839)\end{array}$ & & $\begin{array}{c}0.190 \\
(0.762)\end{array}$ \\
\hline M2/GDP & & $\begin{array}{l}-0.017 \\
(0.118)\end{array}$ & & $\begin{array}{l}-0.006 \\
(0.649)\end{array}$ & & $\begin{array}{l}-0.019 \\
(0.210)\end{array}$ & & $\begin{array}{l}-0.007 \\
(0.590)\end{array}$ & & $\begin{array}{l}-0.009 \\
(0.585)\end{array}$ & & $\begin{array}{c}-0.009 \\
(0.509)\end{array}$ \\
\hline Budget balance & & $\begin{array}{c}0.014 \\
(0.747)\end{array}$ & & $\begin{array}{c}0.054 \\
(0.307)\end{array}$ & & $\begin{array}{l}-0.055 \\
(0.313)\end{array}$ & & $\begin{array}{l}-0.010 \\
(0.851)\end{array}$ & & $\begin{array}{l}-0.008 \\
(0.876)\end{array}$ & & $\begin{array}{c}0.010 \\
(0.844)\end{array}$ \\
\hline Tropical & & $\begin{array}{l}-0.900 \\
(0.023)\end{array}$ & & $\begin{array}{l}-0.555 \\
(0.230)\end{array}$ & & $\begin{array}{l}-0.683 \\
(0.150)\end{array}$ & & $\begin{array}{l}-0.555 \\
(0.235)\end{array}$ & & $\begin{array}{l}-0.542 \\
(0.250)\end{array}$ & & $\begin{array}{l}-0.767 \\
(0.105)\end{array}$ \\
\hline Civil war & & $\begin{array}{c}0.191 \\
(0.698)\end{array}$ & & $\begin{array}{l}-0.326 \\
(0.556)\end{array}$ & & $\begin{array}{c}-0.079 \\
(0.891)\end{array}$ & & $\begin{array}{c}-0.494 \\
(0.479)\end{array}$ & & $\begin{array}{l}-0.128 \\
(0.821)\end{array}$ & & $\begin{array}{c}0.262 \\
(0.657)\end{array}$ \\
\hline East Asia & $\begin{array}{c}-0.351 \\
(0.034)\end{array}$ & $\begin{array}{c}0.331 \\
(0.608)\end{array}$ & $\begin{array}{c}-0.895 \\
(0.000)\end{array}$ & $\begin{array}{c}1.01 \\
(0.268)\end{array}$ & $\begin{array}{c}-0.597 \\
(0.014)\end{array}$ & $\begin{array}{c}0.045 \\
(0.961)\end{array}$ & $\begin{array}{l}-0.460 \\
(0.028)\end{array}$ & $\begin{array}{c}0.566 \\
(0.528)\end{array}$ & $\begin{array}{l}-0.444 \\
(0.035)\end{array}$ & $\begin{array}{c}0.658 \\
(0.518)\end{array}$ & $\begin{array}{l}-0.396 \\
(0.059)\end{array}$ & $\begin{array}{c}0.865 \\
(0.329)\end{array}$ \\
\hline Sub-Saharan Africa & $\begin{array}{c}0.717 \\
(0.000)\end{array}$ & $\begin{array}{c}-1.70 \\
(0.038)\end{array}$ & $\begin{array}{c}0.353 \\
(0.078)\end{array}$ & $\begin{array}{c}-1.61 \\
(0.050)\end{array}$ & $\begin{array}{c}0.858 \\
(0.000)\end{array}$ & $\begin{array}{l}-0.875 \\
(0.351)\end{array}$ & $\begin{array}{c}0.855 \\
(0.000)\end{array}$ & $\begin{array}{c}-1.13 \\
(0.196)\end{array}$ & $\begin{array}{c}0.797 \\
(0.000)\end{array}$ & $\begin{array}{c}-1.32 \\
(0.276)\end{array}$ & $\begin{array}{c}0.684 \\
(0.000)\end{array}$ & $\begin{array}{c}-1.62 \\
(0.057)\end{array}$ \\
\hline Aid repayments & $\begin{array}{c}0.056 \\
(0.199)\end{array}$ & $\begin{array}{l}-0.175 \\
(0.251)\end{array}$ & $\begin{array}{c}0.128 \\
(0.135)\end{array}$ & $\begin{array}{c}0.077 \\
(0.794)\end{array}$ & $\begin{array}{c}0.014 \\
(0.920)\end{array}$ & $\begin{array}{l}-0.331 \\
(0.436)\end{array}$ & $\begin{array}{c}0.110 \\
(0.301)\end{array}$ & $\begin{array}{c}0.184 \\
(0.604)\end{array}$ & $\begin{array}{c}0.081 \\
(0.445)\end{array}$ & $\begin{array}{c}0.124 \\
(0.722)\end{array}$ & $\begin{array}{l}-0.076 \\
(0.563)\end{array}$ & $\begin{array}{l}-0.441 \\
(0.308)\end{array}$ \\
\hline Humanitarian aid & $\begin{array}{l}0.038 \\
(0.634)\end{array}$ & $\begin{array}{c}0.134 \\
(0.624)\end{array}$ & $\begin{array}{c}0.024 \\
(0.751)\end{array}$ & $\begin{array}{c}0.442 \\
(0.110)\end{array}$ & $\begin{array}{l}0.026 \\
(0.831)\end{array}$ & $\begin{array}{c}0.289 \\
(0.429)\end{array}$ & $\begin{array}{c}0.066 \\
(0.458)\end{array}$ & $\begin{array}{c}0.134 \\
(0.659)\end{array}$ & $\begin{array}{c}0.074 \\
(0.407)\end{array}$ & $\begin{array}{c}0.126 \\
(0.681)\end{array}$ & $\begin{array}{l}-0.010 \\
(0.912)\end{array}$ & $\begin{array}{l}-0.190 \\
(0.570)\end{array}$ \\
\hline Initial life expectancy & & & $\begin{array}{l}-0.089 \\
(0.000)\end{array}$ & $\begin{array}{l}0.013 \\
(0.857)\end{array}$ & & & & & & & & \\
\hline Black market premium & & & & & & $\begin{array}{l}-0.009 \\
(0.000)\end{array}$ & & & & & & \\
\hline Post-conflict1 & & & & & & & $\begin{array}{c}0.304 \\
(0.062)\end{array}$ & $\begin{array}{c}0.680 \\
(0.348)\end{array}$ & & & & \\
\hline Non-humanitarian aid & & & & & & & & & & & $\begin{array}{c}0.042 \\
(0.047) \\
\end{array}$ & $\begin{array}{c}0.162 \\
(0.036) \\
\end{array}$ \\
\hline $\begin{array}{l}\text { Countries / Observations } \\
\mathrm{R}^{2}\end{array}$ & $\begin{array}{c}52 / 205 \\
0.872\end{array}$ & $\begin{array}{c}52 / 205 \\
0.459\end{array}$ & $\begin{array}{c}52 / 203 \\
0.824\end{array}$ & $\begin{array}{c}52 / 203 \\
0.410\end{array}$ & $\begin{array}{c}42 / 129 \\
0.814\end{array}$ & $\begin{array}{c}42 / 129 \\
0.352\end{array}$ & $\begin{array}{c}48 / 166 \\
0.847\end{array}$ & $\begin{array}{c}48 / 166 \\
0.335\end{array}$ & $\begin{array}{c}48 / 166 \\
0.844\end{array}$ & $\begin{array}{c}48 / 166 \\
0.333\end{array}$ & $\begin{array}{c}48 / 166 \\
0.847\end{array}$ & $\begin{array}{c}48 / 166 \\
0.350\end{array}$ \\
\hline
\end{tabular}

Notes: p-values in parentheses based on robust standard errors. Constant term and time dummies not reported. Instrumented variables are in bold type. All regression results based on $3 \mathrm{SLS}(\mathrm{t})$ technique. The estimated coefficient of humanitarian aid is qualitatively the same when we use the rest of the techniques: FE( $(\mathrm{t}), \mathrm{FE}(\mathrm{i}, \mathrm{t})$, GMM-DIFF, and GMM-SYS. 
Table 7

Testing the specification: aid interaction effects

\begin{tabular}{|c|c|c|c|c|c|c|c|c|c|c|c|c|}
\hline \multicolumn{13}{|c|}{ Testing the specification: aid interaction effects } \\
\hline & \multicolumn{2}{|c|}{ (1) } & \multicolumn{2}{|c|}{ (2) } & \multicolumn{2}{|c|}{ (3) } & \multicolumn{2}{|c|}{ (4) } & \multicolumn{2}{|c|}{ (5) } & \multicolumn{2}{|c|}{ (6) } \\
\hline & fertility & growth & fertility & growth & fertility & growth & fertility & growth & fertility & growth & fertility & growth \\
\hline Initial GDP per capita $(\log )$ & $\begin{array}{c}0.108 \\
(0.428)\end{array}$ & $\begin{array}{l}-0.537 \\
(0.100)\end{array}$ & $\begin{array}{c}0.069 \\
(0.629)\end{array}$ & $\begin{array}{c}-0.740 \\
(0.034)\end{array}$ & $\begin{array}{c}0.091 \\
(0.509)\end{array}$ & $\begin{array}{l}-0.621 \\
(0.066)\end{array}$ & $\begin{array}{c}0.140 \\
(0.312)\end{array}$ & $\begin{array}{c}-0.544 \\
(0.099)\end{array}$ & $\begin{array}{c}0.172 \\
(0.172)\end{array}$ & $\begin{array}{c}-0.780 \\
(0.010)\end{array}$ & $\begin{array}{c}0.152 \\
(0.222)\end{array}$ & $\begin{array}{c}-0.841 \\
(0.010)\end{array}$ \\
\hline Infant mortality rate & $\begin{array}{c}0.017 \\
(0.000)\end{array}$ & & $\begin{array}{c}0.015 \\
(0.000)\end{array}$ & & $\begin{array}{c}0.016 \\
(0.000)\end{array}$ & & $\begin{array}{c}0.015 \\
(0.000)\end{array}$ & & $\begin{array}{c}0.017 \\
(0.000)\end{array}$ & & $\begin{array}{c}0.015 \\
(0.000)\end{array}$ & \\
\hline Initial school & $\begin{array}{l}-0.021 \\
(0.000)\end{array}$ & & $\begin{array}{l}-0.019 \\
(0.000)\end{array}$ & & $\begin{array}{c}-0.021 \\
(0.000)\end{array}$ & & $\begin{array}{l}-0.021 \\
(0.000)\end{array}$ & & $\begin{array}{l}-0.024 \\
(0.000)\end{array}$ & & $\begin{array}{c}-0.023 \\
(0.000)\end{array}$ & \\
\hline Urban & $\begin{array}{l}-0.006 \\
(0.282)\end{array}$ & & $\begin{array}{l}-0.006 \\
(0.386)\end{array}$ & & $\begin{array}{l}-0.007 \\
(0.239)\end{array}$ & & $\begin{array}{l}-0.007 \\
(0.200)\end{array}$ & & $\begin{array}{l}-0.007 \\
(0.179)\end{array}$ & & $\begin{array}{c}-0.010 \\
(0.088)\end{array}$ & \\
\hline Fertility rate & & $\begin{array}{c}-0.151 \\
(0.737)\end{array}$ & & $\begin{array}{c}-0.695 \\
(0.257)\end{array}$ & & $\begin{array}{c}-0.233 \\
(0.612)\end{array}$ & & $\begin{array}{c}-0.250 \\
(0.596)\end{array}$ & & $\begin{array}{c}-\mathbf{- 0 . 6 4 0} \\
(\mathbf{0 . 0 8 2})\end{array}$ & & $\begin{array}{c}-0.803 \\
(0.067)\end{array}$ \\
\hline Institutional quality & & $\begin{array}{c}0.369 \\
(0.055)\end{array}$ & & $\begin{array}{c}0.272 \\
(0.251)\end{array}$ & & $\begin{array}{c}0.352 \\
(0.072)\end{array}$ & & $\begin{array}{c}0.345 \\
(0.076)\end{array}$ & & $\begin{array}{c}0.343 \\
(0.059)\end{array}$ & & 0.235 \\
\hline Inflation & & $\begin{array}{c}-2.54 \\
(0.005)\end{array}$ & & $\begin{array}{c}-3.42 \\
(0.000)\end{array}$ & & $\begin{array}{c}-3.07 \\
(0.001)\end{array}$ & & $\begin{array}{c}-3.11 \\
(0.001)\end{array}$ & & $\begin{array}{c}-2.90 \\
(0.001)\end{array}$ & & $\begin{array}{c}-3.21 \\
(0.000)\end{array}$ \\
\hline Trade policy & & $\begin{array}{c}0.270 \\
(0.688)\end{array}$ & & $\begin{array}{l}-0.234 \\
(0.757)\end{array}$ & & $\begin{array}{c}0.337 \\
(0.622)\end{array}$ & & $\begin{array}{c}0.267 \\
(0.701)\end{array}$ & & $\begin{array}{c}0.096 \\
(0.877)\end{array}$ & & $\begin{array}{c}0.173 \\
(0.784)\end{array}$ \\
\hline M2/GDP & & $\begin{array}{l}-0.008 \\
(0.580)\end{array}$ & & $\begin{array}{c}-0.012 \\
(0.551)\end{array}$ & & $\begin{array}{l}-0.007 \\
(0.629)\end{array}$ & & $\begin{array}{l}-0.006 \\
(0.724)\end{array}$ & & $\begin{array}{l}-0.010 \\
(0.450)\end{array}$ & & $\begin{array}{c}-0.008 \\
(0.545)\end{array}$ \\
\hline Budget balance & & $\begin{array}{c}0.016 \\
(0.771)\end{array}$ & & $\begin{array}{l}-0.027 \\
(0.642)\end{array}$ & & $\begin{array}{c}-0.015 \\
(0.779)\end{array}$ & & $\begin{array}{c}-0.016 \\
(0.769)\end{array}$ & & $\begin{array}{c}0.009 \\
(0.870)\end{array}$ & & $\begin{array}{c}-0.010 \\
(0.851)\end{array}$ \\
\hline Tropical & & $\begin{array}{c}-0.754 \\
(0.106)\end{array}$ & & $\begin{array}{l}-0.621 \\
(0.211)\end{array}$ & & $\begin{array}{c}-0.456 \\
(0.356)\end{array}$ & & $\begin{array}{c}-0.540 \\
(0.246)\end{array}$ & & $\begin{array}{c}-0.695 \\
(0.140)\end{array}$ & & $\begin{array}{c}-0.439 \\
(0.381)\end{array}$ \\
\hline Civil war & & $\begin{array}{c}0.592 \\
(0.323)\end{array}$ & & $\begin{array}{c}0.182 \\
(0.765)\end{array}$ & & $\begin{array}{c}0.001 \\
(0.998)\end{array}$ & & $\begin{array}{c}-0.349 \\
(0.623)\end{array}$ & & $\begin{array}{c}0.167 \\
(0.770)\end{array}$ & & $\begin{array}{c}-0.161 \\
(0.775)\end{array}$ \\
\hline East Asia & $\begin{array}{l}-0.428 \\
(0.042)\end{array}$ & $\begin{array}{c}1.23 \\
(0.190)\end{array}$ & $\begin{array}{l}-0.604 \\
(0.007)\end{array}$ & $\begin{array}{c}0.938 \\
(0.377)\end{array}$ & $\begin{array}{c}-0.490 \\
(0.022)\end{array}$ & $\begin{array}{c}0.810 \\
(0.401)\end{array}$ & $\begin{array}{l}-0.513 \\
(0.015)\end{array}$ & $\begin{array}{c}0.807 \\
(0.409)\end{array}$ & $\begin{array}{l}-0.423 \\
(0.046)\end{array}$ & $\begin{array}{c}0.891 \\
(0.319)\end{array}$ & $\begin{array}{c}-0.534 \\
(0.012)\end{array}$ & $\begin{array}{c}0.356 \\
(0.711)\end{array}$ \\
\hline Sub-Saharan Africa & $\begin{array}{c}0.774 \\
(0.000)\end{array}$ & $\begin{array}{c}-2.32 \\
(0.016)\end{array}$ & $\begin{array}{c}0.894 \\
(0.000)\end{array}$ & $\begin{array}{c}-1.35 \\
(0.296)\end{array}$ & $\begin{array}{c}0.873 \\
(0.000)\end{array}$ & $\begin{array}{c}-1.82 \\
(0.068)\end{array}$ & $\begin{array}{c}0.930 \\
(0.000)\end{array}$ & $\begin{array}{c}-1.75 \\
(0.093)\end{array}$ & $\begin{array}{c}0.887 \\
(0.000)\end{array}$ & $\begin{array}{l}-0.412 \\
(0.650)\end{array}$ & $\begin{array}{c}0.758 \\
(0.000)\end{array}$ & $\begin{array}{c}-1.24 \\
(0.151)\end{array}$ \\
\hline Aid repayments & $\begin{array}{l}-0.128 \\
(0.368)\end{array}$ & $\begin{array}{c}-0.307 \\
(0.513)\end{array}$ & $\begin{array}{c}0.125 \\
(0.458)\end{array}$ & $\begin{array}{c}0.389 \\
(0.493)\end{array}$ & $\begin{array}{c}0.065 \\
(0.548)\end{array}$ & $\begin{array}{c}0.195 \\
(0.583)\end{array}$ & $\begin{array}{c}0.104 \\
(0.336)\end{array}$ & $\begin{array}{c}0.271 \\
(0.455)\end{array}$ & $\begin{array}{c}0.063 \\
(0.559)\end{array}$ & $\begin{array}{c}0.008 \\
(0.980)\end{array}$ & $\begin{array}{c}0.120 \\
(0.259)\end{array}$ & $\begin{array}{c}0.191 \\
(0.591)\end{array}$ \\
\hline Humanitarian aid & $\begin{array}{c}-0.026 \\
(0.824)\end{array}$ & $\begin{array}{c}-0.618 \\
(0.133)\end{array}$ & $\begin{array}{c}0.057 \\
(0.575)\end{array}$ & $\begin{array}{c}0.093 \\
(0.790)\end{array}$ & $\begin{array}{c}0.080 \\
(0.466)\end{array}$ & $\begin{array}{c}0.119 \\
(0.745)\end{array}$ & $\begin{array}{c}0.077 \\
(0.450)\end{array}$ & $\begin{array}{c}0.039 \\
(0.909)\end{array}$ & $\begin{array}{c}0.155 \\
(0.258)\end{array}$ & $\begin{array}{c}0.944 \\
(0.045)\end{array}$ & $\begin{array}{c}-0.408 \\
(0.110)\end{array}$ & $\begin{array}{c}-0.724 \\
(0.444)\end{array}$ \\
\hline Non-humanitarian aid & $\begin{array}{c}0.053 \\
(0.041)\end{array}$ & $\begin{array}{c}0.167 \\
(0.070)\end{array}$ & & & & & & & & & & \\
\hline Aid repayments squared & $\begin{array}{c}0.008 \\
(0.224)\end{array}$ & $\begin{array}{l}-0.307 \\
(0.513)\end{array}$ & & & & & & & & & & \\
\hline Humanitarian aid squared & $\begin{array}{c}0.001 \\
(0.971)\end{array}$ & $\begin{array}{c}0.137 \\
(0.111)\end{array}$ & & & & & & & & & & \\
\hline Non-humanitarian aid squared & $\begin{array}{l}-0.001 \\
(0.220)\end{array}$ & $\begin{array}{l}-0.001 \\
(0.787)\end{array}$ & & & & & & & & & & \\
\hline Humanitarian aid * policy & & & $\begin{array}{c}-0.203 \\
(0.330)\end{array}$ & $\begin{array}{c}0.654 \\
(0.385)\end{array}$ & & & & & & & & \\
\hline Humanitarian aid * tropical & & & & & $\begin{array}{l}-0.030 \\
(0.784)\end{array}$ & $\begin{array}{l}-0.174 \\
(0.650)\end{array}$ & & & & & & \\
\hline Post-conflict1 & & & & & & & $\begin{array}{c}0.328 \\
(0.048)\end{array}$ & $\begin{array}{c}0.652 \\
(0.382)\end{array}$ & & & & \\
\hline Humanitarian aid * post-conflict1 & & & & & & & $\begin{array}{l}-0.128 \\
(0.412)\end{array}$ & $\begin{array}{c}0.004 \\
(0.994)\end{array}$ & & & & \\
\hline Humanitarian aid * Sub-Saharan Africa & & & & & & & & & $\begin{array}{l}-0.134 \\
(0.436)\end{array}$ & $\begin{array}{c}-1.32 \\
(0.027)\end{array}$ & & \\
\hline Humanitarian aid * high-fertility & & & & & & & & & & & $\begin{array}{c}0.538 \\
(0.044)\end{array}$ & $\begin{array}{c}0.959 \\
(0.336)\end{array}$ \\
\hline Countries / Observations & $46 / 155$ & $46 / 155$ & $44 / 135$ & $44 / 135$ & $46 / 155$ & $46 / 155$ & $46 / 155$ & $46 / 155$ & $48 / 166$ & $48 / 166$ & $48 / 166$ & $48 / 166$ \\
\hline $\mathrm{R}^{2}$ & 0.840 & 0.375 & 0.833 & 0.371 & 0.834 & 0.347 & 0.839 & 0.350 & 0.844 & 0.349 & 0.847 & 0.331 \\
\hline
\end{tabular}

